\title{
Groundwater Arsenic Contamination in the Bengal Delta Plain is an Important Public Health Issue - A Review
}

\author{
Jaydip Sen ${ }^{1} \cdot$ Barry Bogin $^{2} \cdot$ Nitish Mondal $^{3} \cdot$ Sima Dey $^{4} \cdot$ Shreyasi Roy ${ }^{1}$ \\ 1 Department of Anthropology, University of North Bengal, Raja Rammohunpur, Darjeeling 734013, West Bengal, India. \\ ${ }^{2}$ Loughborough University. School of Sport, Exercise and Health Sciences, LE11 3TU, UK. \\ ${ }^{3}$ Department of Anthropology, Sikkim University, Gangtok 737102, Sikkim, India. \\ ${ }^{4}$ Department of Anthropology, University of Calcutta, 35, B. C. Road, Kolkata 700019, West Bengal, India.
}

\section{Citation:}

Sen, J, et al. (2021), Groundwater Arsenic Contamination in the Bengal Delta Plain is an Important Public Health Issue, Human Biology and Public Health 1.

https://doi.org/10.52905/hbph.v1.7.

Received: 2020-11-18

Accepted: 2021-02-12

Published: 2021-06-22

\section{Copyright:}

This is an open access article distributed under the terms of the Creative Commons Attribution License which permits unrestricted use, distribution, and reproduction in any medium, provided the original author and source are credited.

\section{Conflict of Interest:}

There are no conflicts of interest.

\section{Correspondence to:}

Jaydip Sen

email: jaydipsen@rediffmail.com

\section{Keywords:}

public health, arsenic, groundwater, India, Bangladesh, Bengal delta

\begin{abstract}
There is a close association between human biology, epidemiology and public health. Exposure to toxic elements is one area of such associations and global concerns. The Bengal Delta Plain (BDP) is a region where contamination of ground water by arsenic has assumed epidemic proportions. Apart from dermatological manifestations, chronic exposure to arsenic causes a heavy toll through several carcinogenic and non-carcinogenic disorders. This article provides a global overview of groundwater arsenic contamination in the BDP region, especially the sources, speciation, and mobility of arsenic, and critically reviews the effects of arsenic on human health. The present review also provides a summary of comprehensive knowledge on various measures required for mitigation and social consequences of the problem of arsenic contaminated groundwater in the $\mathrm{BDP}$ region.
\end{abstract}

Take home message for students Human biologists can play a significant role in assessing effects of toxic elements on human health. In the Bengal Delta Plain a vast population has been affected by groundwater arsenic contamination. This review will provide impetus to undertake research in this key area of human health and toxic elements. 


\section{Introduction}

There has been a gradual increase in the demand for research in anthropology in the areas of public health over the years. Quoting Goodenough (1963), it is quite prudent to assume that anthropology has long-standing interests in human biocultural development generally, and particular interests in public health and medicine. Human biology as a subject of study is not as antique as physical anthropology. The term "human biology" was not used to describe a separate subfield of biology until the $20^{\text {th }}$ Century. It was Raymond Pearl, Professor of Biometry and Vital Statistics at Johns Hopkins University, who was the first modern biologist to use the term "human biology". Very recently, Nelson et al. (2019) suggested that the subfields of biological anthropology included primatology, paleoanthropology, molecular anthropology, bio-archaeology, forensic anthropology and human biology. They went on to state that many biological anthropologists conduct research that comes under the label of "human biology". This type of research is varied, but tends to explore how the human body is impacted by different physical environments, cultural influences and nutrition. As a matter of fact some years earlier, Baker (1982) proposed that "human biology" could be better referred to as "human population biology". Very importantly, it is now recognized that the bio-cultural approach remains well suited to understand the interrelationship of urbanism and human biology (Schell and Denham 2003). More recently, Stinson et al. (2012) published several definitions of human biology, all of which emphasize,

"[...] that the biology of the human species is studied from a variety of disciplines, each with its own perspective. These disciplines vary from the practical applications of clinical medicine for the treatment of human disease to studies to better understand the basic physiological pathways and mechanisms in the human body to research aimed at understanding the adaptive/evolutionary context of human biology".

Human exposure to different toxic elements (e.g., lead, arsenic, mercury and cadmium) has been a significant public health concern over the years Schell and Denham (2003). This is an area of research where human biologists can have a significant role to play. One noteworthy anthropologist of toxic pollution is L. M. Schell, Distinguished Professor of Anthropology, Epidemiology and Biostatistics, at the University of Albany, State University of New York, United States. In a noteworthy publication, (Schell and Denham 2003; Schell et al.) observed that urban living today involved several biological challenges, of which one was pollution. They went on to suggest using three different types of pollutants as examples, air pollution, lead, and noise, as how the impact of pollution on various aspects of human biology (e.g., mortality, morbidity, reproduction, and development) can be observed. In another publication, Schell et al. (2009) have comprehensively analyzed the effects of cigarette smoking, air pollution, organic compounds, lead, radiation and noise stress on human growth. In a later publication, Schell et al. (2010) further stated that to achieve the comprehensive and holistic approach characteristic of human biological research, investigators should include measures of pollutant exposure. In fact Schell et al. (2006) went on to define pollution as "a material or a form of energy that is unwanted, usually because it is believed to be detrimental to health and wellbeing". 


\section{Background on arsenic and arsenic poisoning}

Arsenic (As) is a widely dispersed natural rare crystal metallic element whose existence has been known since the time of Aristotle. It exists at an average concentration of about $5 \mathrm{mg} / \mathrm{kg}^{-1}$ (Garelick et al. 2008) and comprises about $0.00005 \%$ of the earth's crust (Gulledge and O'Connor 1973). In abundance this element is ranked $20^{\text {th }}$ in the earth's crust, $14^{\text {th }}$ in the seawater and $12^{\text {th }}$ in the human body (Braman 1975). The element is a world-wide environmental pollutant and a persistent bioaccumulative human carcinogen ((Rahman et al. 2003), (Ghosh et al. 2007; Guha Mazumder and Dasgupta 2011; Rahman et al. 2003; Ruiz de Luzuriaga et al. 2011; Kile et al. 2016; Chen et al. 2005; Shih et al. 2020).

Sporadic reports of As poisoning through drinking water in the past have been reported by Wyllie (1937), Tseng et al. (1968) and Grantham and Jones (1977). Recent reports of high concentrations of As in groundwater from different regions of the world are now available. Globally this has led to a large number of people, residing in almost 70 countries, being currently affected by groundwater As contamination (Chowdhury et al. 2000; Smith et al. 2000; Mukherjee et al. 2008; Bundschuh et al. 2010; Naujokas et al. 2013). The primary reason underlying this exposure is prolonged use of groundwater as the population's principle source of drinking water, thus being a direct major source of As contamination (Pontius et al. 1994; Chowdhury et al. 2000; Thakur and Gupta 2019). Water is the principal medium through which this element is transported in environmental and biological systems (Huysmans and Frankenberger 1990; Styblo et al. 2000). Chronic As toxicity has become a global human health threat due to consumption of groundwater naturally contaminated with As (Khalequzzaman et al. 2005; Ghosh et al. 2008; Guha Mazumder and Dasgupta 2011; Argos et al. 2012; Thakur and Gupta 2019).

Information on different affected areas in Asia prior to 2000 was relatively scarce with few major incidents of As contamination in groundwater reported (Das et al. 1994; Ahmed and Amin 1997; Mandal et al. 1998; Subramanian and Kosnett 1998; Chatterjee and Mukherjee 1999). It was only with the discovery of newer contaminated regions some years later that the extent of the problem could be comprehended. At present, the category of the most severely affected countries comprises Bangladesh, India, Myanmar and Afghanistan (Chowdhury et al. 2000; Khalequzzaman et al. 2005; Mukherjee et al. 2006; van Geen et al. 2014; Hayat and Baba 2017). Several other affected Asian countries are China (Guo et al. 2001; Zhang et al. 2012; Xie et al. 2013; Sanjrani et al. 2019), Vietnam (Berg et al. 2001; Buschmann et al. 2008; Hanh et al. 2011; Le Luu 2019), Nepal (Shrestha et al. 2003; Yadav et al. 2012; Mueller 2017), Cambodia (Gault et al. 2008; Kim et al. 2011; Murphy et al. 2018), Indonesia (Winkel et al. 2008; Bentley and Soebandrio 2017), Korea (Ahn 2012; Bae et al. 2017) and Pakistan (Fatmi et al. 2009; Brahman et al. 2013; Shaikh et al. 2018). The magnitude of the problem can be further gauged from a study which claimed that more than 45 million people mainly in developing countries of Asia were exposed to more than $50 \mu \mathrm{g} / \mathrm{L}$ of As, which was thought to be the maximum concentration limit in drinking water in several Asian countries (Ravenscroft et al. 2009).

\section{Main affected regions in Asia}

One of the major areas in Asia that has been severely affected by this menace is the BDP. In the BDP, over 100 million 
people have been affected by As exposure through drinking water drawn from underground sources that contained As well above the permissible limit (Ravenscroft et al. 2009; Inauen et al. 2013). The World Health Organization (WHO) has described this as the worst instance of mass poisoning in history.

The BDP is formed by the Ganga-MeghnaBrahmaputra (GMB) river basin and covers several districts of the state of West Bengal in India and several districts of Bangladesh. This region is now considered the worst As affected alluvial basin in the world (Chowdhury et al. 2000; Smith et al. 2000; Ghosh et al. 2008; Chakraborti et al. 2018). The BDP is recognized as the largest modern delta of the world and has been formed by extensive amounts of Quaternary sediments that have been transported downstream by the GMB river system. This river system originates in the Himalayas and flows through India, Nepal, and China before flowing into Bangladesh and finally into the Bay of Bengal. It forms the main drainage system of the BDP. The meandering GMB river system has deposited a thick layer of sediments during the late Quaternary or Holocene eras (Mukherjee and Bhattacharya 2001). The overbank sediments are rich in organic matter. The BDP covers a surface area of approximately $100.000 \mathrm{~km}^{2}$. About two-thirds of the delta is in Bangladesh, while the rest lies in the state of West Bengal, India. The BDP is one of the most fertile regions in the world and is very densely populated. In this region, agricultural activities are usually dependent on groundwater.

The inhabitants of this region are exposed to water that is naturally and heavily contaminated with As. The basic question that crops up here is how the people of these areas suddenly became exposed to As through drinking water. To unravel this question, one has to traverse back 60 years in time. In the 1960s and 1970s, the govern- ments of both countries were strongly committed to containing outbreaks of different water-borne diseases. The surface sources of water are subject to fecal contamination, thus giving rise to diseases such as diarrhoea, dysentery, typhoid, cholera and hepatitis. It was believed that groundwater was relatively free from pathogenic microorganisms and readily available in shallow aquifers in the BDP. So in order to reduce the consumption of bacteria contaminated surface water, a large number of shallow tube wells (having a maximum depth of $<150 \mathrm{~m}$ ) were drilled in the BDP (Hossain 2006).

Sinking of these shallow tube wells (Figure 1) in the BDP was preferred mainly for the following three reasons:

a) Easy availability of the underground aquifers at shallow depths from the surface $(<150 \mathrm{~m})$.

b) The process of sinking such tube wells was very simple.

c) The tube wells had a low cost of installation.

The number of such tube wells sunk in the region increased over the years. Water contaminated with As was being pumped out and being used for the dual purposes of drinking and irrigation. It has been estimated that almost $85 \%$ of such water being pumped out was used for irrigating the crops during the lean dry season. 


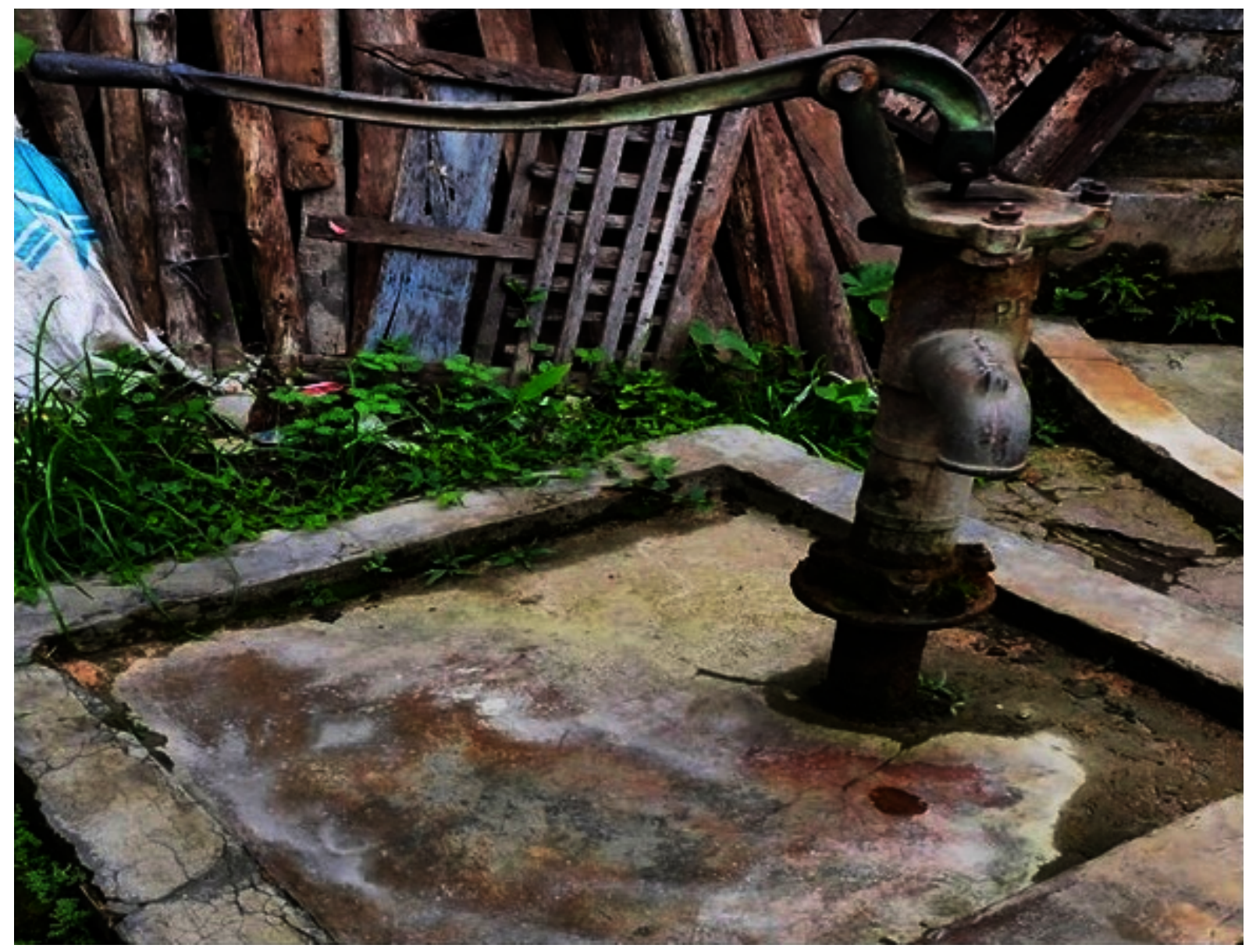

Figure $1 \mathrm{~A}$ tube well from an As contaminated area in West Bengal, India

\section{Permissible limits of As in groundwater}

Since 1958 the WHO had regularly taken stated positions on the health risks of arsenic in drinking-water. Successive editions of "International standards for drinking water" and "Guidelines for drinkingwater quality" have published reviews of the data which have led to a progressive lowering of the standard values in response to emerging evidence of significant health concerns. The WHO recommended safety limit of As is $10 \mu \mathrm{g} / \mathrm{L}$ and a maximum permissible limit is $50 \mu \mathrm{g} / \mathrm{L}$ in drinking water (Steinmaus et al. 2005). The Indian and the Bangladesh national drinking water permissible limits are identical to that of WHO at $50 \mu \mathrm{g} / \mathrm{L}$ (Chowdhury et al. 2000; Ghosh et al. 2008; Chakraborti et al. 2009). Recently there have been re-evaluations of the toxic effects of As on humans by different governmental agencies around the world. These re-evaluations were based on the fact that As exposure exhibited the potential to cause health effects at lower concentrations than was previously thought. This conclusion has now led to a lowering of As limits in drinking water in many countries. The United States has subsequently lowered the permissible limit from $50 \mu \mathrm{g} / \mathrm{L}$ to $10 \mu \mathrm{g} / \mathrm{L}$ (Welch et al. 2018), while in Canada the limit has been lowered from $50 \mu \mathrm{g} / \mathrm{L}$ to $25 \mu \mathrm{g} / \mathrm{L}$, with a proposal to lower it further to 5 $\mu \mathrm{g} / \mathrm{L}$ (Saint-Jacques et al. 2018). The fact remains that no such lowering of the As levels is yet to be proposed in India and Bangladesh, the two countries where the exposure through groundwater is the most widespread and acute. However, recent 
studies have also expressed doubts as to whether the WHO proposed $10 \mu \mathrm{g} / \mathrm{L}$ is a safe limit or not (Chakraborti 2016; Ahmad and Bhattacharya 2019).

\section{Extent of As Groundwater Contamination in the BDP}

\section{The Indian scenario}

Early survey reports documented As contamination in groundwater in the Union Territory of Chandigarh and surrounding the northwestern Upper Ganga Plain of Bihar (Bhojpur, Buxar and Sahebganj districts) and Jharkhand (Chakraborti et al. 2003; Singh 2006). The contamination also subsequently spread over the Ganga-Ghagra Plain. A two-year survey on groundwater As contamination in the districts of Ballia, Varanasi and Gazipur of Uttar Pradesh in the upper and middle Ganga Plains reported As concentrations to be $>50 \mu \mathrm{g} / \mathrm{L}$ (Steinmaus et al. 2005; Ahmad and Bhattacharya 2019). Extremely high As concentration of $3192 \mu \mathrm{g} / \mathrm{L}$ was observed in some tube well water samples indicating that individuals from a significant part of Uttar Pradesh were exposed to As (Ahamed et al. 2006a). New areas in Kanker district of Madhya Pradesh have also reported a high mean As concentration of $144 \mu \mathrm{g} / \mathrm{L}$ (Pandey et al. 2006). Arsenic contamination has also been reported from the Brahmaputra Plain (Chakraborti et al. 2004). The north-eastern states of Assam, Tripura, Manipur, Arunachal Pradesh and Nagaland have been affected. Of the 24 districts in Assam, 21 of them which included Barpeta, Dhemaji, Dhubari, Darrang, Golaghat, Jorhat and Lakhimpur were significantly affected with As levels of 100-200 $\mu \mathrm{g} / \mathrm{L}$. High As concentrations are also found in the districts of West Tripura $(191 \mu \mathrm{g} / \mathrm{L})$, North Tripura $(122-283 \mu \mathrm{g} / \mathrm{L})$ and Dhalai in Tripura $(65-444 \mu \mathrm{g} / \mathrm{L})$, the district of Thoubal in Manipur (798-986 $\mu \mathrm{g} / \mathrm{L})$, the district of Dibang in Arunachal Pradesh $(618 \mu \mathrm{g} / \mathrm{L})$ and the districts of Mokokchung (50-278 $\mu \mathrm{g} / \mathrm{L}$ ) and Mon in Nagaland (67-159 $\mu \mathrm{g} / \mathrm{L})$ (Singh 2004). With more studies being initiated in this field, As contamination of the groundwater resources is now being reported from various regions of India. Apparently, As contamination of groundwater resources has been a phenomenon that has rapidly spread its tentacles throughout the country (Chakraborti et al. 2003; Ahamed et al. 2006a; Chauhan et al. 2012; Thakur and Gupta 2019).

\section{The West Bengal scenario}

In the state of West Bengal, the Holocene alluvium and deltaic aquifers of the BDP is the region where As contamination of groundwater is the maximum. In December 1983, 63 people from three villages under two districts were identified as suffering from As toxicity and this was the first reported instance of groundwater As contamination among humans from West Bengal (Chakraborti et al. 2002). The magnitude of the problem can be understood in terms of sheer numbers of individuals exposed (36 million) and geographical area covered $\left(173 \times 10^{3} \mathrm{~km}^{2}\right)$. Das et al. (1994) reported that 6 districts of West Bengal were worst affected by As contamination. By the next few years, the number of affected districts increased to 9, which covered an area of $38,865 \mathrm{~km}^{2}$, affecting 42.70 million individuals in 985 As-affected villages in 69 police stations/blocks (Chowdhury et al. 2000; Rahman et al. 2003). By September 2006, the number of affected districts had increased to 12 within which 111 blocks were considered to be affected. These districts were Murshidabad, Maldah, Nadia, 
North 24-Parganas, South 24-Parganas, Barddhaman, Howrah, Hoogly, Kolkata, Koch Bihar, North Dinajpur and South Dinajpur. The affected districts have been grouped under three sub-categories:

(i) Unaffected areas with less than 10 $\mu \mathrm{g} / \mathrm{L}$ (eight districts: Alipurduar, Kalimpong, Birbhum, Bankura, Purulia, Jhargram, Purba Medinipur, Paschim Medinipur)

(ii) Mildly affected areas with As concentration in the range of $10-50 \mu \mathrm{g} / \mathrm{L}$ (six districts: Darjeeling, Jalpaiguri, Cooch Behar, North Dinajpur, South Dinajpur, Paschim Barddhaman)

(iii) Severely affected areas with As level $>300 \mu \mathrm{g} / \mathrm{L}$ (i.e., maximum As concentration found was to be $3200 \mu \mathrm{g} / \mathrm{L}$ in some tested water samples) in remaining districts of North-24-Parganas, South-24-Parganas, Murshidabad, Nadia, Malda, Howrah, Hooghli, Kolkata, Barddhaman) (Chakraborti et al. 2009; Shukla et al. 2020).

\section{The Bangladesh scenario}

Smith et al. (2000) and Sarker (2010) observed that contamination of groundwater by As in Bangladesh was perhaps the single largest poisoning occurence in history, with millions of people exposed and affected. Millions of hand pumps and/or tube wells have been installed since the 1970s and have led to 95\% of the country's 130 million residents becoming dependent on supposedly pathogen-free groundwater (Ahmad et al. 2018). A report of the National Arsenic Mitigation Information Centre in 2008 observed that out of 4.8 million tube wells evaluated by field testing kits, almost $30 \%$ of them exhibited As levels exceeding $50 \mu \mathrm{g} / \mathrm{L}$. The report further concluded that if the population continued to consume As contaminated water, then a major increase in the incidence of diseases caused by As could be predicted.
Arsenic in groundwater was first detected in well water in western Bangladesh in 1993 (Fazal et al. 2001). But it was only in 1998 when it was realized that As contamination in groundwater was developing into a major issue and this led to the organizing of the International Conference on Arsenic in Dhaka (Dhar et al. 1998). It has been reported that 42 districts in Bangladesh exhibited groundwater As levels well above the $>50 \mu \mathrm{g} / \mathrm{L}$ permissible limit (Chowdhury et al. 2000; Steinmaus et al. 2005; Ahmad and Bhattacharya 2019). This study further identified the extent of the area and the population of these 42 districts to be 92,106 sq. $\mathrm{km}$ and 79.90 million respectively and added that 492 villages in 141 police stations/blocks of the area were affected. Within the next 3 years, 59 out of 64 districts had been affected by groundwater As contamination (Khan et al. 2003). The most affected regions comprised the Meghna flood plain and the coastal areas of Khulna. Khalequzzaman et al. (2005) estimated that about $30 \%$ of the private wells in Bangladesh exhibited high concentrations of As $(>50 \mu \mathrm{g} / \mathrm{L})$, with over half the country's administrative units (269 out of 464 units) being affected. Chakraborti et al. (2010) observed that As contamination at levels above $10 \mu \mathrm{g} / \mathrm{L}$ were affecting 36.60 million individuals in 59 districts, while As levels above $50 \mu \mathrm{g} / \mathrm{L}$ were affecting 22.70 million individuals in 50 districts of the country. It was estimated that of 125 million habitats in the country, 35 million to 77 million individuals were being exposed to the carcinogenic effects of As through drinking water (Dhar et al. 1998; Smith et al. 2000). Moreover, 1 out of 5 deaths were attributed to this exposure (Argos et al. 2010). The extent of As contamination in Bangladesh has been further discussed by several researchers (Yunus et al. 2016; Ahmad et al. 2018). 


\section{Sources of As in Groundwater in the BDP}

The average concentration of As in groundwater is $1-2 \mathrm{mg} / \mathrm{kg}$ (Singh 2006). There are two main sources of As in groundwater. One comprises the natural processes such as dissolution of As containing bedrocks and the other is the anthropogenic processes (Lacasa et al. 2011).

\section{Natural sources of As in groundwater}

Realgar $\left(\mathrm{As}_{2} \mathrm{~S}_{2}\right)$ and orpiment $\left(\mathrm{As}_{2} \mathrm{~S}_{3}\right)$ are the two principal mineral sources of As. An exhaustive list of the minerals that contain As has been prepared by Hossain (2006) and this list contains more than 245 such minerals. There are a number of natural processes such as volcanic eruption, weathering (erosion from local rocks) dissolution of minerals and ores and transportation by natural forces (through water/air) that remain chiefly responsible for As enrichment both in the ground and the groundwater. Several isolated geological sources for As have been recognized in the Indian subcontinent by researchers. Examples of such sources are Gondwana coal seams in the Raj Mahal Basin (As: 0.20\%), mica belt of Bihar (As: $0.08 \%-0.12 \%$ ), pyrite-bearing shale from the Proterozoic Vindhya mountain range (As: $0.26 \%$ ), gold belt of Son Valley (As: $2.80 \%$ ) and Himalayan belt of Darjeeling (As: 0.80\%) (Singh 2006). The Bengal basin has one of the world's densest water diversion constructions on the natural courses of rivers. The most important water diversion is the Farakka Barrage on the river Ganges. It has been observed that diversion of water through this barrage and other constructions upstream had significantly reduced flow rate of the river by 2,5 times (Adel 2005). The resulting effects were felt downstream. One effect was that groundwater subsequently began to be rapidly pumped out in the areas downstream for the purposes of drinking and irrigation.

\section{Anthropogenic sources of As in the groundwater}

Combustion of fossil fuel remains one of the most important anthropogenic sources of As emission in the environment ( $\mathrm{Pa}-$ cyna 1987; Vahidnia et al. 2007). Metallurgic plants, cement factories, incineration plants and chemical industries also have vital roles to play in enrichment of As in the environment (Ghosh et al. 2008). The element is also utilized as an ingredient in alloying agents, lead industries, leaching of metals from coal-ash tailing - all of which release appreciable amounts of As in the atmosphere. Widespread use of arsenical pesticides, herbicides and crop desiccants also introduce As into the atmosphere. The element gets removed from the air through settling or rainfall and then finally reaches groundwater through leaching.

\section{Factors Responsible for the High Concentrations of As in the BDP}

\section{Geological factors in the BDP}

There was an initial presumption that the probable source of As lay within the geological formations of the Himalayas (Jain 2002). It is now generally accepted that major sources of As contamination in groundwater of the BDP are the geological deposits and that its release is primarily due to natural processes (Hossain 2006; Akter and Ali 2011). Since the GMB river system has mainly contributed to build up 
of the Bengal delta, the possible source of As had to lie within the Himalayan mountain belt. However, this element is very mobile and can be easily removed and recombined from the source during alteration, transportation and mobilization in the sediments. This is a major handicap in the endeavour to pinpoint the exact sources of As.

Most researchers are of the opinion that the GMB river system flow over the major geological sources of As in the Himalayan mountain belt. These rivers bring lots of river borne materials which include As from the hilly areas to be deposited downstream. It has been estimated that this river system transports 1060 million tons of suspended solids, $1330 \mathrm{~km}^{3}$ of water and 173 million tons of dissolved substances to the Bay of Bengal (Singh 2006). As a result, the concentration of As gradually increases in areas downstream. The BDP has a considerable number of shallow aquifers ( $<100 \mathrm{~m}$ in depth) which are chiefly formed by persistent rainfall and flood waters. Groundwater occurs very near to the ground surface and water chemistry is anoxic in nature. Other important factors that have significant roles to play in higher As concentrations in the BDP are abundance of clay, fine grain and shallow water depths $(4.50 \mathrm{~m}-7.50 \mathrm{~m})$. All these parameters have significant roles to play in the vertical distribution of As in soil.

Existence of As-rich iron pyrites in sediments of the BDP is responsible for release of this element in the aquifers (Roychowdhury 2008). The average concentration of As in these iron pyrites exceeds 2,000 $\mathrm{mg} / \mathrm{kg}$. It has also been reported that the enrichment of As is more prevalent in the proximity of river Ganges. Moreover, concentrations of As have generally been observed to be in higher concentrations in the shallow aquifers of this plain (Stollenwerk et al. 2007; Halim et al. 2010). It was further proposed by Acharyya and Shah
(2007) that late Quaternary stratigraphy, geomorphology and sedimentation may have influenced groundwater As contamination in the alluvium that aggraded during rise of sea levels during the Holocene. But no specific source of As in the BDP could be pinpointed. Khalequzzaman et al. (2005) had analysed four competing hypotheses, each addressing sources, reaction mechanisms, pathways, and sinks of As in groundwater in the context of geologic history and landuse practices in the BDP and concluded that none of these hypotheses alone could explain the observed variability in As concentrations over time and space.

A thorough search of the existing literature has generated three hypotheses regarding As contamination of groundwater in the BDP. The first is the pyrite oxidation hypothesis (Roychowdhury 2008), the second is the oxyhydroxide reduction hypothesis (Nickson et al. 1998; Acharyya et al. 1999) and the third is the oxidation-reduction hypothesis (Moore et al. 1988).

\section{Irrigation activities}

There has been a spurt in irrigational activities in the BDP over the years and groundwater began to be used extensively for this purpose. Millions of cubic meters of groundwater contaminated with high levels of As were flowing out from both hand operated tube wells used by the villagers for their daily needs and shallow big diameter tube wells installed for purpose of irrigation and began to be deposited in the soil all through the year (Roychowdhury et al. 2008; Sharma and Flora 2018)(Roychowdhury et al. 2008516be7074db68e143bb5f7ba. The shallow groundwater which is often rich in As is widely used for irrigation, especially for cultivation of the dry season "Boro" rice. In the long term, this may lead to increasing As content in rice paddy soils, which in turn has a cascading effect on 
rice yields, food quality and human health (Roychowdhury 2008). It has been estimated that in Bangladesh, under the current cultivation practices, the amount of As in the topsoil would substantially increase by the year 2050 (Dittmar et al. 2010). The issue shall remain unsolved even if As-free drinking water is assured to the exposed individuals. The practice of irrigating soils with As contaminated groundwater will continue for years to come, until and unless alternate arrangements are made. This As contaminated groundwater became sources of both drinking water and irrigation water for the individuals residing in the affected regions (Rowland et al. 2009). As this exposure continued, one is faced with the daunting scenario of both humans and the food chain being significantly affected by this element.

With the use of As-polluted water for irrigation purposes, As is being added to soils and crops. These in turn have a cascading effect and pose serious threats to sustainable agricultural production in the BDP and to the health and livelihoods of affected people (Brammer and Ravenscroft 2009). Studies have reported that crops and vegetables grown in the BDP and irrigated by As contaminated groundwater, contained high levels of As (Roychowdhury et al. 2002b; Meharg and Rahman 2003; Brammer and Ravenscroft 2009; Samal et al. 2011; Rahaman et al. 2013). Studies have reported very high levels of As in vegetables cultivated in an As affected area and suggested that the skin of most vegetables absorb As (Roychowdhury et al. 2002b; Roychowdhury et al. 2008). Roychowdhury et al. (2002a) reported that As concentration in soil decreased with distance from the source increased. It has also been observed that high levels of As were found in vegetables imported to England from Bangladesh (Al Rmalli et al. 2005). It has also been observed that rice grown with As contaminated irrigated water showed a pronounced decline in grain trace-nutrient quality with increasing As content (Williams et al. 2009).

\section{Metabolism of Arsenic}

Metabolism is a fundamental issue relating to high As contamination of groundwater resources. It refers to the biological response vis-à-vis clinical manifestations and effects of As.

\section{Biomonitoring and biomarkers of As exposure}

Biomonitoring of human exposure to As reflects an individual's current body burden to this element. The body burden is a function of recent and/or past exposure and this is where correct selection and measurement of biomarkers of As exposure is of prime significance. A biomarker basically is an objective biological measure that is utilized to assess health or make a diagnosis of disease. A number of definitions of the word "biomarker" have been advanced over the years. Rockett and Kim (2005) have defined a biomarker as "any biological index capable of being measured, which is associated with or indicative of a defined biological endpoint such as development or disease stage". The definition proposed by the National Institute of Health (NIH) may also be referred to here. The official NIH definition of a "biomarker" is "...a characteristic that is objectively measured and evaluated as an indicator of normal biologic processes, pathogenic processes, or pharmacologic responses to a therapeutic intervention" (Biomarkers Definitions Working Group 2001). Wang and Fowler (2008) have presented a pertinent review on this topic. 
The traditional biomarkers of blood, fingernails, urine and hair have been successfully utilized to determine As toxicity among affected individuals (Huyck et al. 2007; Samanta et al. 2007). Mandal et al. (2004) reported that As levels in urine, fingernails and hair were positively correlated with concentrations of the same in drinking water. Pandey et al. (2007) went on to observe that any one of these biomarkers could be utilized to document exposure to As. Gault et al. (2008) also concluded that As content in hair, nails and drinking water were highly correlated, and that such samples were easy to collect, store and analyse. This study further concluded that these tissues were effective biomarkers of As. Chen et al. (2005) proposed use of hair, urine and fingernails as biomarkers for short-time exposure ( $<1$ year). However, they differed from other researchers when they concluded that skin hyper-pigmentation and palmo-planter hyperkeratosis were better biomarkers for long-time exposure ( $>1$ year). Use of blood as a biomarker towards As exposure was studied in detail by Hall et al. (2006) who concluded that despite its limitations, blood appeared to be a useful biomarker of As exposure. The main limitation was that As is present in very low concentrations in blood and as a result it remained undetectable by conventional atomic absorption techniques. The use of total urinary As as a biomarker was critically evaluated by Hughes (2006) who raised questions regarding the reliability of measurement of urinary As and the relationship between As in urine and in other target tissues. Rivera-Núñez et al. (2010) have compared As concentrations in First Morning Void (FMV) urine and Spot urine samples. They preferred the use of Spot urine samples instead of FMV samples primarily because of budgetary and logistical considerations. The use of nails has also been subjected to critical analysis. Slotnick and Nriagu (2006) went on to observe that human nail clippings have been the primary biomarker in many recent epidemiological studies relating to As exposure. It was also concluded that toe nails could be a useful indicator of internal As exposure (Schmitt et al. 2005). It has now been proposed that human saliva can also be used as a potential biomarker to document As exposure through drinking water (Yuan et al. 2008). However, detailed studies remain to be initiated using this biomarker. Studies have also focused on oxidative stress and damage caused by As exposure through drinking water. It has been observed by de Vizcaya-Ruiz et al. (2009) that urinary excretion of $8-\mathrm{OHdG}$ and the comet assay of lymphocytes were the primary biomarkers of oxidative DNA damage caused by As.

\section{Effects of groundwater As contamination on humans}

\section{Arsenicosis}

Individuals regularly exposed to As over a prolonged period are known to suffer from arsenicosis which is a multisystem disorder and is now emerging as a major human health issue in the BDP. The time frame for developing arsenicosis varies from 6 months to 2 years, depending on a number of factors such as the concentration of arsenic in the water and amount of water consumed. The definition of arsenicosis as advanced by the WHO is a "chronic health condition arising from prolonged ingestion (not less than 6 months) of As above a safe dose, usually manifested by characteristic skin lesions, with or without involvement of internal organs" (World Health Organization 2003). The magnitude and prevalence of arsenicosis has started to be reported from several Asian countries such as Pakistan, China, Myanmar, Afghanistan and Cambodia (Mukherjee 


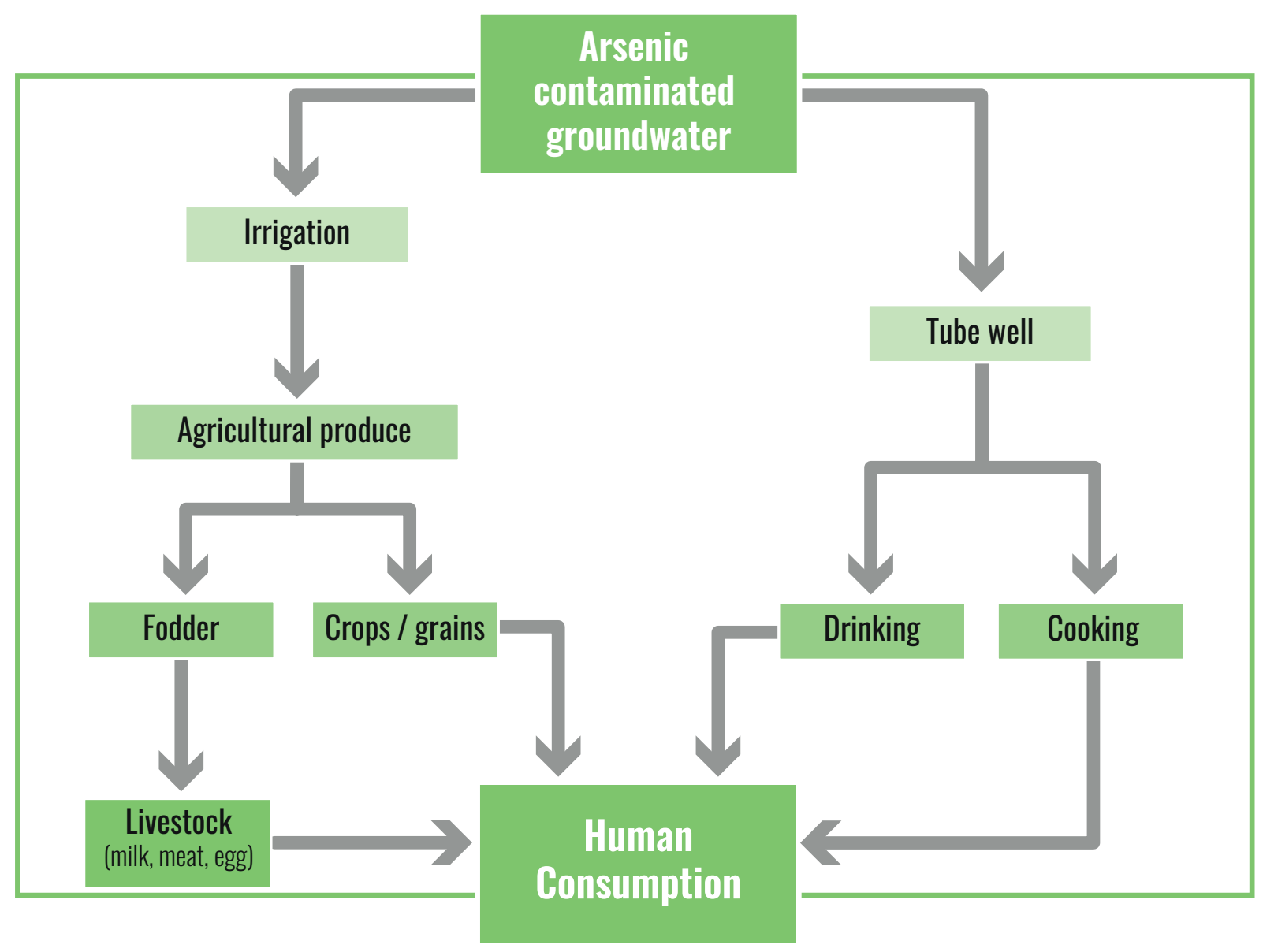

Figure 2 The routes of human exposure to groundwater As

et al. 2006). Several research studies have confirmed that chronic arsenicosis has already affected several Indian states situated on the Gangetic-Brahmaputra river plain (Chakraborti et al. 2002; Mukherjee et al. 2006). The states of Assam (Goswami et al. 2020), Manipur (Singh et al. 2013), Bihar (Thakur and Gupta 2019), Chhattisgarh (Acharyya et al. 2001) and Uttar Pradesh (Ahamed et al. 2006a) are some of the affected states, along with the country of Bangladesh. However, the actual extent of contamination and prevalence of skin diseases caused by As might be many times greater than the actual prevalence. For instance, it has been estimated that over a million people residing in 9 districts have been exposed to As contaminated water (>50 $\mu \mathrm{g} / \mathrm{L}$ ) (Chowdhury et al. 2000; Ghosh et al. 2008), and estimation of the number of individuals with arsenicosis exceeded 200,000 individuals (Das et al. 1995; Guha Mazumder et al. 1998). Lower socio-economic status has also shown to exert a significant influence on arsenicosis (Spallholz et al. 2004). Several studies have reported that poor nutritional status may also increase susceptibility to chronic As toxicity (Sarkar and Mehrotra 2005; Ahmad et al. 2007). Therefore, nutritional management can greatly aid in alleviation of arsenicosis (Sharma and Flora 2018).

\section{Effects on the skin}

Prolonged ingestion of As contaminated water above the permissible limit usually manifested by the characteristics of skin lesions such as melanosis and keratosis, occurring with or without involvement of internal organs (Zeng and Zhang 2020). Skin lesions are the most common manifes- 


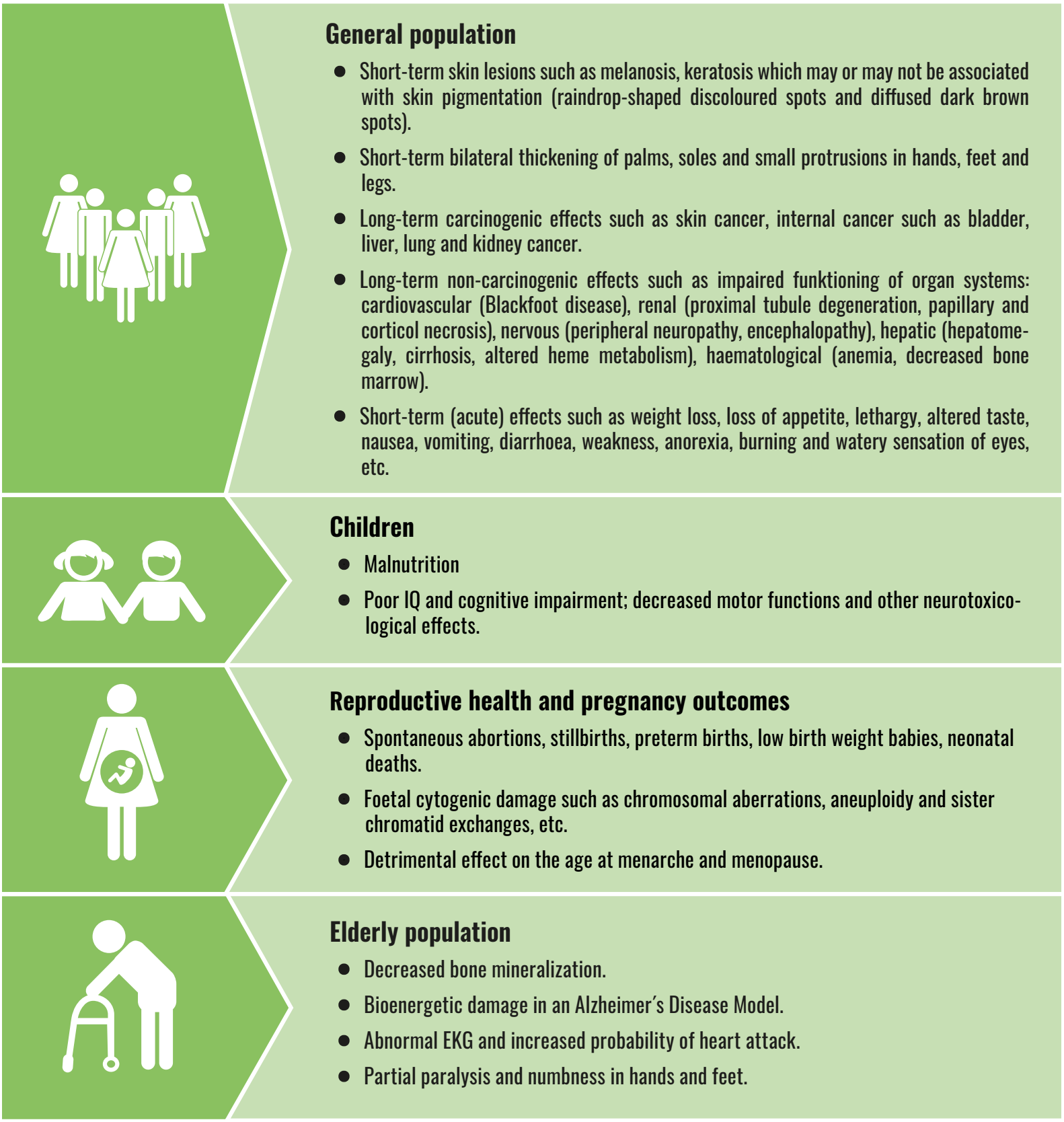

** Individuals are often encountered with one or a combination of symptoms listed above: death also occurs in severe cases

Figure 3 Human health effects of As poisoning

tations in As exposed individuals leading to skin cancers (Mukherjee et al. 2005; Mayer and Goldman 2016) and skin problems. Follow-up studies indicated that most of the individuals who suffered from severe arsenical skin lesions for several years were now suffering from cancer or have already died of cancer. Individuals affected with high As were also observed to have an absence of skin lesions but ex- hibit other clinical manifestations such as weakness, anaemia, diarrhoea, hepatomegaly and lung disease. Studies have reported that vitamin B (e.g., thiamine, riboflavin, niacin, pyridoxine, and cobalamin), vitamins $\mathrm{A}$, vitamins $\mathrm{C}$, vitamins $\mathrm{E}$ and other nutrients such as iron, calcium, fiber, etc. may reduce the risk of As related skin lesions if dietary recommended allowances were greater than the 
current recommended daily amounts in Bangladesh (Zablotska et al. 2008; Melkonian et al. 2012). The dietary consumption of selenium was reported to be adversely affected by chronic ingestion of As (Spallholz etal. 2004). Guha Mazumder and Dasgupta (2011) reported that deficiency in DNA repair capacity, perturbation of methylation of promoter region of p53 and p16 genes, and genomic methylation alteration may be involved in As-induced disease manifestation in humans. The P53 polymorphism has been observed to be associated with increased occurrence of As-induced keratosis in West Bengal.

\section{Carcinogenic effects of As}

This element is considered to be Class-I human carcinogen by the International Agency for Research on Cancer because of its increased risks for skin, bladder and lung cancers (Ruiz de Luzuriaga et al. 2011). Epidemiological studies suggest that As exposure and internal cancers of bladder, liver, lung and kidney are strongly related (Guha Mazumder and Dasgupta 2011; Ruiz de Luzuriaga et al. 2011; Yuan et al. 2018). It has been estimated that between 200,000-270,000 cancer deaths in Bangladesh were attributed to As exposure (Smith et al. 2000). Chen and Ahsan (2004) have indicated a doubling of future excess mortality in Bangladesh owing to cancers of lung, liver and bladder as a result of consuming As contaminated drinking water. Evaluated data from health effects of As longitudinal studies have revealed risks of mortality and chronic disease mortality increased with increasing arsenical toxicity exposure especially in long-term exposure (Argos et al. 2010). Interestingly, even though individuals with skin lesions were more susceptible to As-induced toxicity, individuals without skin lesions were also sub-clinically affected and were also susceptible to As-induced toxicity and carcinogenicity when compared to individuals unexposed to As (Ghosh et al. 2007). To understand the carcinogenic effects of As, exposure to inorganic and organic As needs to be distinguished. Only exposure to inorganic As has been observed to be associated with cancers (Pershagen 1981; Järup et al. 1989), and inorganic As has been considered a human carcinogen for a long time (Tokar et al. 2010). For centuries, inorganic As has been utilized as a poison. Initial reviews on long-term inorganic As exposure have portrayed its carcinogenic effects. In all probability, the first report on the association between inorganic As and skin cancer was published in 1888 (Hutchinson 1888). Since then a number of studies have tried to link the development of tumours to As exposure. Subsequently, the International Agency for Research on Cancer started the process of reviewing available experimental and epidemiological data on inorganic As exposure among humans and concluded that As was a skin and lung carcinogen (IARC 1980). Reviews have also commented on the carcinogenic nature of this element (Naujokas et al. 2013; Costa 2019).

\section{Other health effects}

Affected individuals also suffer from with weight loss, lost of appetites, lethargy, burning and watering sensation of eyes, swelling of legs, liver fibrosis, chronic respiratory disease, conjunctival congestion, non-cirrhotic portal fibrosis, gangrene of toes, oedema of limbs, polyneuropathy and gastrogenital symptoms of anorexia, nausea, dyspepsia and altered taste (Chattopadhyay et al. 2010; Guha Mazumder and Dasgupta 2011). In very long-term As exposure, systematic symptoms are most commonly gastro-intestinal symptoms as well as peripheral neuropathy and these may lead to skin lesions (Chattopadhyay et al. 2010; Chen et al. 2009). However, 
studies on neuropathic patients of arsenicosis and long-term toxic neurological effects remain largely unexplored and unknown (Mukherjee et al. 2003). Studies have also confirmed that a lower body mass index is associated with a greater prevalence of skin lesions, supporting that all over malnutrition may increase the risk of As related skin diseases and other health ailments (Guha Mazumder et al. 1998; Ahsan et al. 2006; Deb et al. 2013).

\section{As exposure and pregnancy outcome}

Arsenic content in drinking water and duration of exposure may be responsible for increasing susceptibility of pregnant women to spontaneous abortions, stillbirths, preterm births, low birth weights, and neonatal deaths (Mukherjee et al. 2005; Ahamed et al. 2006b; Kile et al. 2016). It has also been observed that there have been instances of chromosomal aberrations, aneuploidy and sister chromatid exchanges due to long term exposure to As through consumption of contaminated water. This was indicative of cytogenetic damage (Mahata et al. 2003). Of the various genotoxic effects of As in humans, chromosomal aberration and increased frequency of micronuclei in different cell types have been found to be significant (Guha Mazumder and Dasgupta 2011). There is limited evidence to show that exposure to high concentrations of As during pregnancy increases the risk of stillbirth (Ehrenstein et al. 2007), although a study has reported higher incidence of stillbirth and miscarriages in pregnant women exposed to As through groundwater than normal controls in Bangladesh (Milton et al. 2005; Kwok et al. 2006). Studies have indicated that exposure to As may have a detrimental effect on menarche (attainment of menarche at a late age) and increase the incidence of stillbirths and spontaneous abortions (Sen and Chaud- huri 2007; 2008). High concentrations of As, greater than or equal to $200 \mu \mathrm{g} / \mathrm{L}$ in the drinking water $(\mathrm{N}=167)$, during pregnancy were observed to be associated with a six-fold increased risk for stillbirth (Guha Mazumder and Dasgupta 2011). Ahmad et al. (2001) reported that induced As toxicity in drinking water showed adverse pregnancy outcomes in terms of spontaneous abortions, stillbirths and preterm birth rates in Bangladesh. Kwok et al. (2006) reported a significant association between As exposure and birth defects in Bangladesh. Moreover, several animal model studies on mice have reported that continuous exposure to As causes placental dysmorphogenesis and defective placental vasculogenesis resulting in placental insufficiencies and subsequent miscarriages (Waalkes et al. 2004; He et al. 2007) and this may also be a mechanism in humans. A very recent observational study found higher prenatal As exposure to be associated with longer birth length, greater head circumference and lower ponderal index (Shih et al. 2020).

\section{As exposure and child mortality and morbidity}

Infants and children are more vulnerable to the adverse effects of any toxic substance such as As and this is a primary cause of high morbidity rate among them. Exposure to As has an effect on the IQ of children. Ehrenstein et al. (2007) reported that As exposures were associated with small decrements in intellectual testing in school-aged children. A similar study also reported significant negative associations of As exposure with cognitive impairment and decreased performance in mathematics among children from Bangladesh (Asadullah and Chaudhury 2011). Recently, a study has reported that As exposure was associated with substantial increased risk of death at a young age from all causes, and cancers and cardiovascular diseases. Girls and adolescents aged 
12-18 years had increased risks compared to boys and children in Bangladesh (Rahman et al. 2019).

\section{Mobilization of As in the Groundwater}

Mobilization of this element depends on the geochemistry of As as this plays a vital role in the release and subsequent transport of As in groundwater. It is primarily governed by the geochemical and hydrogeological characteristics of alluvial sediments. The mobility is also dependent on the microbial degradation in presence of organic substrates in reducing aquifers (Bhattacharya et al. 1997). The phenomenon of As mobilization is further dependent upon As speciation, ion chemistry and sediment grain size.

\section{Arsenic speciation}

The twin factors of $\mathrm{pH}$ and redox have the potentials to play important roles in As speciation (Mohan and Pittman 2007). The commonly existing species of As in groundwater are inorganic and organic As. Other oxidized states of As can also exist in water. These are arsenic $\left(\mathrm{As}^{0}\right)$ and arsine $\left(\mathrm{As}^{3-}\right)$.

\section{Inorganic As}

Arsenic is primarily present in inorganic forms and exists in two predominant species: arsenate $\left(\mathrm{As}^{5+}\right)$ and arsenite $\left(\mathrm{As}^{3+}\right)$. Arsenite is much more toxic, soluble, and mobile than arsenate (Ferguson and Gavis 1972; Deuel and Swoboda 1972). However, convincing epidemiological evidence indicates that trivalent As is more toxic than pentavalent As, although both valences have been classified to be carcinogenic (World Health Organization 2003). Arsenite is converted to arsenate by the process of oxidation and vice versa by the process of reduction. This process of conversion is fundamental to As mobilization. The main sources of inorganic As are sulphide minerals and metal-oxides (especially iron). Although readily absorbed by humans, most of inorganic As (>90\%) is rapidly cleared from the blood with a half-life of 1-2 hours and $40-70 \%$ of As intake is absorbed, metabolized and excreted within 48 hours (Cohen et al. 2006).

\section{Organo As}

Organo As is less toxic and harmful for human health and is eliminated by the body (Fazal et al. 2001). It is abundant in sea food, plants, fish and crabs and is formed from inorganic As through a process of biomethylation.

Within the reducing aquifers in the BDP, mobilization of As occurs by microbial degradation in the presence of organic substrates (Bhattacharya et al. 1997). The burial of organic matter along with the sediments facilitates microbial activity. This, in turn, plays an important role in the generation of reducing conditions (McArthur et al. 2001). Although the rate of As release reactions under these conditions is dependent on a number of factors, they are likely to be relatively rapid on a geological time scale. However, the nature of the organic matter involved in the generation of reducing conditions in As affected aquifers has now been disputed (Harvey et al. 2002).

\section{Ion chemistry}

Retention or mobility of As is strongly dependent on the redox (oxidation reduction) conditions of the aqueous and mineral phases of groundwater. Moderately reducing conditions are viewed to be quite 
favorable for release of As from the sediments.

It has been observed that As content is positively correlated with $\mathrm{Fe}, \mathrm{PO}_{4}{ }^{3-}$ and $\mathrm{NH}_{4}{ }^{+}$, but the correlation is lower with $\mathrm{Mn}$ and $\mathrm{Cu}$ (Sarifuzzaman et al. 2007). As released during the weathering of pyrite $\mathrm{FeS}_{2}$ is generally adsorbed onto the surface of iron oxy-hydroxides that have precipitated under oxidizing conditions generally prevailing during deposition of the sediments. However, redox processes in the sediments trigger reductive dissolution of iron oxides that transfers substantial amounts of As in aqueous phases through bio-geochemical interactions (Amaya 2002).

Iron arsenate $\left(\mathrm{FeAsO}_{4}\right)$ may be tentatively regarded as the direct and immediate source of As. This is because it is easily formed from scorolite $\left(\mathrm{FeAs}_{4}, 2 \mathrm{H}_{2} \mathrm{O}\right)$ and pitticite (hydrated mixture of arsenate and sulphate), which are common alternation products of arseno-pyrite. During the process of hydrolysis under low $\mathrm{pH}$ and high Eh (redox potential) conditions, ferric arsenate is dissociated into the strongly toxic arsenic acid $\left(\mathrm{H}_{3} \mathrm{AsO}_{4}\right)$ with ferric hydroxide, whereas ferric arsenite breaks down into arsenious acid $\left(\mathrm{H}_{3} \mathrm{AsO}_{3}\right)$ and ferric hydroxide (Singh 2006). Soil redox levels can greatly affect toxic trace elements uptake by plants (Gambrell and Patrick 1989) and leaching losses of toxic elements by runoff or groundwater (Palermo et al. 1989).The oxidation/reduction state (redox potential, Eh) of soil is an important parameter affecting As transformation (Signes-Pastor et al. 2007). The redox conditions of soils vary widely from approximately $+500 \mathrm{mV}$ (surface soils) to approximately $-300 \mathrm{mV}$ (strongly reducing conditions). Analysis of grain size of sediments revealed that the clay strata between $4.50 \mathrm{~m}-7.50 \mathrm{~m}$ in depth are responsible for vertical distribution of As. It has been reported that extensive groundwater withdrawal for agriculture favours the oxidation of As-rich iron sulphide and thereby mobilizing As (Nickson et al. 1998). Arsenic concentrations were also observed to increase with decreasing grain size of sediments (Xie et al. 2009).

\section{Mitigation}

Mitigation refers to alternative sources for safe drinking water supply to the affected individuals and basically includes the intervention/mitigation methods. It has to be kept in mind that the selection of appropriate methods to supply water with reduced As content to the people residing in the BDP has to be based on several factors. This becomes more complicated as the majority of the people are rural based, devoid of proper infrastructural and heath facilities. It has been clearly advocated that such mitigation strategies should address both technological and the socioeconomic considerations (Heijnen 2003). The various available options suited for getting drinking water with low As content can be divided into two categories by Shankar et al. (2014) which include:

- finding an alternative As-free water source,

- removal of As from the existing water source.

The various modes for providing As-free drinking water cab be divided into two main categories which are:

- alternative As-free water sources

- methods for removal of As from groundwater.

The alternative As-free water sources are comprised of deep tube well, shallow groundwater (well switching), dug well water, surface water and rain water harvesting. The methods for removal of As from groundwater are coagulation-flocculation, oxidation and adsorption. 
Mitigation means of As contamination can be two-edged. On the one hand, there are several issues related to devising scientifically sound, cost-effective, locally acceptable methods, which should be sustainable through community involvement. Problems remain with respect to hazard substitution, which may undermine As removal achievements in the long run (Ghosh et al. 2008). Mandal et al. (1998) referred to a noteworthy declining trend of skin lesions in a group of affected individuals when As-free water was administered to them over a long period. So, the fundamental intervention involves identification and provision of As-free drinking water. Community education and participation are essential to ensure that such interventions are successful and these should be coupled with follow-up monitoring to confirm that exposure has ended. However, drinking water quality regulatory standards as well as guidelines are yet to cover risk assessments for such metal toxicity (Bhattacharyya et al. 2003). It is of paramount importance to identify those existing water sources exhibiting high levels of As (above the permissible limit). Initially field test kits may be utilized as they are inexpensive and easy to use. However, the results obtained need to be confirmed by specific tests in the laboratory. The water sources need to be monitored and screened on a regular basis.

There are several efficient technologies for the removal of As from groundwater. These include treatment of surface, river and pond water, using deeper tube wells (>150 mts in depth) to extract groundwater that have low concentrations of As, rainwater harvesting and exploring low technology, low cost, locally manufactured As removal plants. In the middleincome countries of India and Bangladesh, the best option is probably the latter one and this has received widespread attention over the past few years. However, all these methods have their own disadvantages. The treatment of surface, river and pond water involves setting up of large water purification and distribution plants which are time consuming and expensive (Sarkar et al. 2010). Since the concentration of As is low in deeper aquifers, use of deeper tube wells ( $>150$ meter in depth) appears to be another option. But the use of deeper tube wells has only a limited value (Stollenwerk et al. 2007). Moreover, increased extraction of deeper groundwater for the purposes of irrigation in the BDP can lead to the tricking down of the As contaminated groundwater from the shallow aquifers. Rainwater harvesting is another natural source of As-free water but its initial high cost makes it economically unviable (Visoottiviseth and Ahmed 2008). The As removal plants also have high costs of installation and/or operation. These also produce As contaminated filter sludge that needs to be disposed of properly so that the As does not go back to the environment. However, Hoque et al. (2004) observed that often As filter plants were abandoned within a few weeks of installation. These required too much attention, discharged small volumes of water at low rates, were difficult to maintain, and discharged poor quality water. For As affected areas, it was recommended that a cluster-based piped water system be given proper consideration when selecting appropriate water options rather than household-based options or the development of new low-cost options (Hoque et al. 2004). Interestingly, preference of the rural people was observed to be predominantly in favour of the piped water when compared with other As mitigation technologies (Ahmad et al. 2006). It was also shown by Hossain (2006) that As removal plants were ineffective in removing As from the water. Berg et al. (2006) showed that sand filters proved to operate at faster rates and were robust for a broad range of groundwater composition and 
could be a viable option for As mitigation. Another option that has been explored very recently is to target As-safe/free aquifers (Bundschuh et al. 2010). It is suggested here that for the mitigation programmes to be successful in the BDP, it remains essential to develop comprehensive removal and/or management system of As contaminated water involving sufficient available medical and infrastructural support within the reach of primary healthcare services (Ghosh et al. 2008).

\section{Awareness and Social Issues}

With chronic As exposure now emerging to be a major public health concern due to its carcinogenicity (Naujokas et al. 2013), focus needs to be on widespread social problems it creates for its victims and their families. It needs to be emphasized here that although there have been major efforts in finding ways and means to supply As-free water to the people, the roles of public education and awareness have not yet received substantial focus. One important notion that needs to be dispelled among the affected individuals is that boiling removes As from water (George et al. 2013). An important issue that also needs to be addressed is to educate the population about why tube wells once thought to be trusted are now considered unsafe. The basic foundation for creating awareness was pertinently summed up by Hanchett et al. (2002) when they observed that explaining the various ways and means of As in groundwater together with water testing, encouraging people to ask questions, repeating the messages, educating children about risks and effects of As contaminated water and involving the community as a whole are the most important strategies. It has also been observed that testing tube well water for As contamination has the potential to create curiosity and interest among the affected populations (Hadi 2003). This potential needs to be fully explored and As-removal plants could be made the symbol of As mitigation. Another important point that needs to be addressed is the differences in awareness levels of the individuals residing in the low and the high-risk areas. Paul (2004) has observed that awareness levels were not perceivable among those individuals inhabiting As low risk regions and that gaps remained in the knowledge about As poisoning, arsenicosis and mitigation. Moreover, education, gender, age, socioeconomic status along with levels of risks was strong determinants in creating awareness. Figures 4 and 5 shows two arsenic awareness camps being organized in Deganga block of North 24-parganas, West Bengal.

There appears to be a tendency to ostracize As affected people primarily because arsenicosis is thought to be a contagious disease. Within the community, As affected people are often barred from social activities and face rejection, even by their immediate family members. Women with visible symptoms of arsenicosis are unable to get married and often, married housewives who are exposed are divorced. Children with symptoms are not sent to school in an effort to hide the issue. Hassan et al. (2005) observed that patients' experiences reveal severe negative social impacts and a sharp difference of perceptions about As and social issues between individuals suffering from arsenicosis and those unaffected by this disease or often due to discrete social taboos, customs or social acceptance. Furthermore, several studies have reported that consequences such as social stigmatization can occur as cutaneous manifestations of arsenicosis were incorrectly thought to indicate a contagious disease, leading to marital discord, 
employment difficulties and social isolation in the population (Ahmad et al. 2007; Goswami et al. 2020).

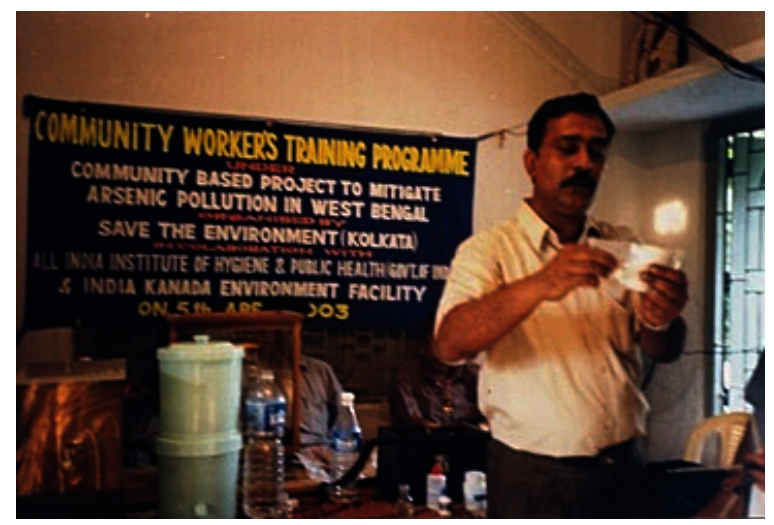

Figure 4 An As awareness camp being organised in Deganga Block, North 24-Parganas, West Bengal, India (Source: UGC Grant No: F.PSW-022/03-04)

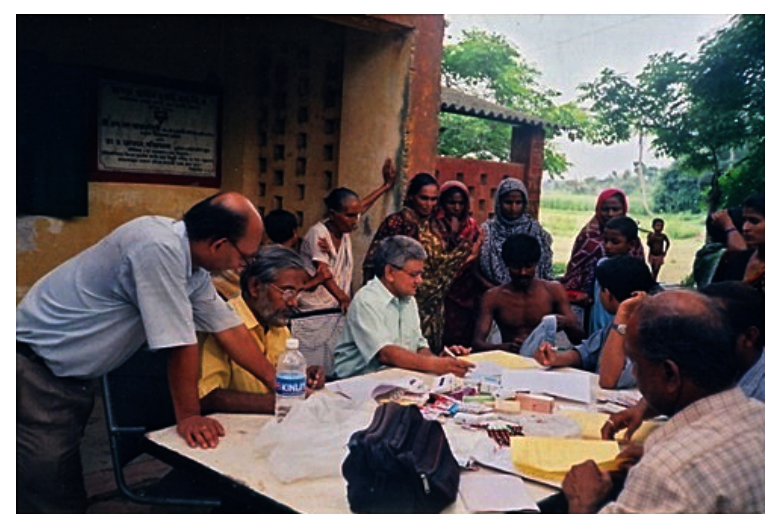

Figure 5 Another As awareness camp being organised in Deganga Block, North 24-Parganas, West Bengal, India (Source: Grant No: F.PSW-022/03-04)

Based on a field experience of nearly two decades in Bangladesh, Ahamed et al. (2006b) emphasized the importance of creating awareness among people in connection with the As problem, role of As-free water, better nutrition from local fruits and vegetables, and, above all, active participation of women along with others in the struggle against this danger. Only then would a mitigation programme yield fruitful results. In another study from Bangladesh, it was observed that an individual's awareness about the As threat was strongly influenced by word of mouth, education and number of children (Aziz et al. 2006). There has been a tendency of willingness to reduce As exposure by using As-free safe water and this again is related to perception of health risks (Parvez et al. 2006). This study further observed that levels of awareness were higher among male individuals and those having better housing facilities and engaged in higher occupations. However, Nahar et al. (2008) reported that male individuals residing in rural areas were more susceptible to arsenicosis than females. They also noted that income had a significant effect on exposure. A striking result of their study was also that most of the individuals were willing to financially contribute and also walk a distance to obtain As-free water.

Results of another study conducted in an As endemic area in Bangladesh stressed the different aspects of health care (Ahmad et al. 2007). It was observed that the individuals knowingly had to consume As-contaminated water from the tube wells as no other alternative sources of water were available. The study also highlighted the different problems that remain associated with the individuals who continue to be exposed to As toxicity. Such problems include long waiting time in the health centers, locations of the health centers that are often far away, discrimination in providing healthcare, no separate facilities for women and non-availability of the medicines in the health centers. It was also observed that those from lower income groups were more likely to face both economic and social problems. The role of the alternative healthcare providers like homeopaths and village quack doctors were also discussed. A study has also focused on the different social factors affecting use of deep tube wells that provide As-free drinking water (Mosler et al. 2010). This study revealed that social factors had a significant role to play here and that 
social norms seem to strongly influence deep tube well use. So the individuals need to be educated and made aware of the health issues of As exposure. Myths relating to arsenicosis need to be dispelled. Awareness about regularly monitoring the water sources and sources of As-free water should be also created. The perception of the people towards the health effects of As was also studied by Sarker (2010) who reported that As poisoning was the chief contributing factor causing a number of social and psychological problems. Education and income had strong roles to play in the perception of health effects of As. Women were, however, less susceptible towards social problems than men. Sarker (2010) also emphasized the importance of awareness programmes, but added that such programmes should take into account the understanding of people's perceptions and social and psychological issues related to As exposure.

\section{Conclusion}

The primary reason behind the problem of As in the BDP is thought to be geogenic, though there are to be several instances of reported anthropogenic contamination of As in groundwater from industrial sources. The main reason for leaching of As in groundwater can be attributed to various factors such as excessive withdrawal of groundwater of the purpose of drinking and irrigation. From the foregoing presentation, it is apparent that groundwater As contamination is indeed a major public health problem in the BDP. Large sections of the population of the region are consuming As contaminated water. The need of the hour is to organize awareness camps, specialty clinics for treatment of patients, proper monitoring of As status of individuals by biomarkers and to provide safe As-free drinking water. Health check-up camps and intervention programmes are also required to reduce As related mortality and morbidity in effected regions. Introduction of regular monitoring and treatment of the people exposed to As are also required. Programmes should focus on reduction of As exposure, early diagnosis and treatment on reduction of As induced diseases such as, arsenicosis and skin cancer. Such efforts need to be multi-disciplinary and holistic. There should be some preventive law to control and constantly monitor installations of hand pumps/tube wells, industries and As removal plants in order to restrict As contamination in groundwater. Although the available methods have their own advantages and disadvantages, novel pragmatic approaches need to be followed to prevent As contamination in the BDP. The development of alternative operationally and economically feasible preventive measures for the people living in As affected areas are necessary to combat and to reduce effects of As related adverse health consequences in future.

The review is a comprehensive one and has tried to encompass all the issues related to arsenic contamination in ground water, especially in the BDP. Undoubtedly, anthropology has a great role to play in this research field. In fact, both social-cultural anthropology and human biology have the potential to make significant impacts to address this long-lasting public health concern in effected region. However, this issue is outside the purview of this review and so the authors have not touched upon it. It can be a subject matter of another paper. But the authors believe that this is an area where indeed human biology can be "transdisciplinary" in nature. 


\section{Authors' Contributions}

All the authors have significantly contributed towards the preparation, review and the writing of the manuscript.

\section{Acknowledgements}

The authors gratefully acknowledge the help and advice rendered by Prof. Dr. Michael Hermanussen and PD Dr. Christiane Scheffler in the course of preparation of the manuscript.

\section{References}

Acharyya, S. K./Ashyiya, I. D./Pandey, Y./Lahiri, S./Khongan, V. W./Sarkar, S. K. (2001). Arsenic contamination in groundwater in parts of Ambagarh Chowki Korse Kohari belt (Dongargarh-Kotri rift zone), Chhattisgrah. In: National symposium role of earth sciences in integrated development and related societal issues, 2-4 November 2001, Lucknow. special publication 65 (I). Kolkata, Geological Survey of India, vii-xviii.

Acharyya, S. K./Chakraborty, P./Lahiri, S./Raymahashay, B. C./Guha, S./Bhowmik, A. (1999). Arsenic poisoning in the Ganges delta. Nature 401 (6753), 545; discussion 546-7. https://doi.org/10.1038/44052.

Acharyya, Subhrangsu K./Shah, Babar A. (2007). Groundwater arsenic contamination affecting different geologic domains in India - a review: influence of geological setting, fluvial geomorphology and Quaternary stratigraphy. Journal of Environmental Science and Health. Part A, Toxic/Hazardous Substances \& Environmental Engineering 42 (12), 1795-1805. https://doi.org/10.1080/10934520701566744.

Adel, M. M. (2005). The background state leading to arsenic contamination of Bengal basin groundwater. Journal of Water and Health 3 (4), 435-452. https://doi.org/10.2166/wh.2005.053.

Ahamed, S./Kumar Sengupta, M./Mukherjee, A./Amir Hossain, M./Das, B./Nayak, B./Pal, A./Chandra Mukherjee, S./Pati, S./Nath Dutta, R./Chatterjee, G./Srivastava, R./Chakraborti, D. (2006a). Arsenic groundwater contamination and its health effects in the state of Uttar Pradesh (UP) in upper and middle Ganga plain, India: A severe danger. The Science of the Total Environment 370 (2-3), 310-322. https://doi.org/10.1016/j.scitotenv.2006.06.015.
Ahamed, S./Sengupta, M. K./Mukherjee, S. C./Pati, S./Mukherjeel, A./Rahman, M. M./Hossain, M. A./Das, B./Nayakl, B./Pal, A./Zafar, A./Kabir, S./Banu, S. A./Morshed, S./Islam, T./Quamruzzaman, Q./Chakraborti, D. (2006b). An eight-year study report on arsenic contamination in groundwater and health effects in Eruani village, Bangladesh and an approach for its mitigation. Journal of Health, Population, and Nutrition 24 (2), 129-141.

Ahmad, A./Bhattacharya, P. (2019). Arsenic in drinking water: is $10 \mu \mathrm{g} / \mathrm{L}$ a safe limit? Current Pollution Reports 5 (1), 1-3. https://doi.org/10.1007/s40726-019-0102-7.

Ahmad, J./Goldar, B./Misra, S. (2006). Rural communities' preferences for arsenic mitigation options in Bangladesh. Journal of Water and Health 4 (4), 463-477.

Ahmad, S. A./Khan, M. H./Haque, M. (2018). Arsenic contamination in groundwater in Bangladesh: implications and challenges for healthcare policy. Risk management and healthcare policy 11, 251-261. https://doi.org/10.2147/RMHP.S153188.

Ahmad, S. A./Sayed, M. H. S./Khan, M. H./Karim, M. N./Haque, M. A./Bhuiyan, M. S. A./Rahman, M. S./Faruquee, M. H. (2007). Sociocultural aspects of arsenicosis in Bangladesh: community perspective. Journal of Environmental Science and Health. Part A, Toxic/Hazardous Substances \& Environmental Engineering 42 (12), 1945-1958. https://doi.org/10.1080/10934520701567247.

Ahmad, S. Akhtar/Sayed, M. H. Salim Ullah/Barua, S./Khan, M. Haque/Faruquee, M. H./Jalil, A./Hadi, S. Abdul/Talukder, H. Kabir (2001). Arsenic in Drinking Water and Pregnancy Outcomes. Environmental Health Perspectives 109 (6), 629. https://doi.org/10.2307/3455038.

Ahmed, I./Amin, A. (1997). Arsenic on tap. People \& the Planet 6 (3).

Ahn, J. S. (2012). Geochemical occurrences of arsenic and fluoride in bedrock groundwater: a case study in Geumsan County, Korea. Environmental Geochemistry and Health 34 (1), 43-54. https://doi.org/10.1007/s10653011-9411-5.

Ahsan, Habibul/Chen, Y./Parvez, F./Argos, M./Hussain, A. I./Momotaj, H./Levy, D./van Geen, A./Howe, G./Graziano, J. (2006). Health Effects of Arsenic Longitudinal Study (HEALS): description of a multidisciplinary epidemiologic investigation. Journal of Exposure Science \& Environmental Epidemiology 16 (2), 191-205. https://doi.org/10.1038/sj.jea.7500449.

Akter, A./Ali, M. H. (2011). Arsenic contamination in groundwater and its proposed remedial measures. International Journal of Environmental Science \& Technology 8 (2), 433-443. https://doi.org/10.1007/BF03326230. 
Al Rmalli, S. W./Haris, P. I./Harrington, C. F./Ayub, M. (2005). A survey of arsenic in foodstuffs on sale in the United Kingdom and imported from Bangladesh. The Science of the Total Environment 337 (1-3), 23-30. https://doi.org/10.1016/j.scitotenv.2004.06.008.

Amaya, A. (2002). Arsenic in groundwater of alluvial aquifers in Nawalparasi and Kathmandu districts of Nepal. Stockholm, 2002.

Argos, M./Ahsan, H./Graziano, J. H. (2012). Arsenic and human health: epidemiologic progress and public health implications. Reviews on environmental health 27 (4), 191-195. https://doi.org/10.1515/reveh-2012-0021.

Argos, M./Kalra, T./Rathouz, P. J./Chen, Y./Pierce, B./Parvez, F./Islam, T./Ahmed, A./Rakibuz-Zaman, M./Hasan, R./Sarwar, G./Slavkovich, V./van Geen, A./Graziano, J./Ahsan, H. (2010). Arsenic exposure from drinking water, and all-cause and chronic-disease mortalities in Bangladesh (HEALS): a prospective cohort study. The Lancet 376 (9737), 252-258. https://doi.org/ 10.1016/S0140-6736(10)60481-3.

Asadullah, M. N./Chaudhury, N. (2011). Poisoning the mind: Arsenic contamination of drinking water wells and children's educational achievement in rural Bangladesh. Institute for the Study of Labor. Bonn. IZA Discussion Papers 5716. Available online at http://nbnresolving.de/urn:nbn:de:101:1-201106013290.

Aziz, S. N./Boyle, K. J./Rahman, M. (2006). Knowledge of arsenic in drinking-water: risks and avoidance in Matlab, Bangladesh. Journal of Health, Population, and Nutrition 24 (3), 327-335.

Bae, H.-S./Kang, I.-G./Lee, S.-G./Eom, S.-Y./Kim, Y.D./Oh, S.-Y./Kwon, H.-J./Park, K.-S./Kim, H./Choi, B.-S./Yu, I.-J./Park, J. D. (2017). Arsenic exposure and seafood intake in Korean adults. Human \& Experimental Toxicology 36 (5), 451-460. https://doi.org/10.1177/0960327116665673.

Baker, P. T. (1982). Human population biology: a viable transdisciplinary science. Human biology 54 (2), 203-220.

Bentley, K./Soebandrio, A. (2017). Arsenic and mercury concentrations in marine fish sourced from local fishermen and fish markets in mine-impacted communities in Ratatotok Sub-district, North Sulawesi, Indonesia. Marine pollution bulletin 120 (1-2), 75-81. https://doi.org/10.1016/j.marpolbul.2017.04.058.

Berg, M./Luzi, S./Trang, P. T. K./Viet, P. H./Giger, W./Stüben, D. (2006). Arsenic removal from groundwater by household sand filters: comparative field study, model calculations, and health benefits. Environmental Science \& Technology 40 (17), 5567-5573. https://doi.org/10.1021/es060144z.
Berg, M./Tran, H. C./Nguyen, T. C./Pham, H. V./Schertenleib, R./Giger, W. (2001). Arsenic contamination of groundwater and drinking water in Vietnam: a human health threat. Environmental Science \& Technology 35 (13), 2621-2626. https://doi.org/10.1021/es010027y.

Bhattacharya, P./Chatterjee, D./Jacks, G. (1997). Occurrence of Arsenic-contaminated Groundwater in Alluvial Aquifers from Delta Plains, Eastern India. Options for Safe Drinking Water Supply. International Journal of Water Resources Development 13 (1), 79-92. https://doi.org/10.1080/07900629749944.

Bhattacharyya, R./Chatterjee, D./Nath, B./Jana, J./Jacks, G./Vahter, M. (2003). High arsenic groundwater: mobilization, metabolism and mitigationan overview in the Bengal Delta Plain. Molecular and Cellular Biochemistry 253 (1-2), 347-355. https://doi.org/10.1023/a:1026001024578.

Biomarkers Definitions Working Group (2001). Biomarkers and surrogate endpoints: preferred definitions and conceptual framework. Clinical pharmacology and therapeutics 69 (3), 89-95. https://doi.org/10.1067/mcp.2001.113989.

Brahman, K. D./Kazi, T. G./Afridi, H. I./Naseem, S./Arain, S S./Wadhwa, S. K./Shah, F. (2013). Simultaneously evaluate the toxic levels of fluoride and arsenic species in underground water of Tharparkar and possible contaminant sources: a multivariate study. Ecotoxicology and Environmental Safety 89, 95-107. https://doi.org/10.1016/j.ecoenv.2012.11.023.

Braman, R. S. (1975). Arsenic in the Environment. In: Arsenical Pesticides. American Chemical Society, 108-123.

Brammer, H./Ravenscroft, P. (2009). Arsenic in groundwater: a threat to sustainable agriculture in South and South-east Asia. Environment International 35 (3), 647-654. https://doi.org/10.1016/j.envint.2008.10.004.

Bundschuh, J./Litter, M. I./Bhattacharya, P. (2010). Targeting arsenic-safe aquifers for drinking water supplies. Environmental Geochemistry and Health 32 (4), 307-315. https://doi.org/10.1007/s10653-010-9308-8.

Buschmann, J./Berg, M./Stengel, C./Winkel, L./Sampson, M. L./Trang, P. T. K./Viet, P. H. (2008). Contamination of drinking water resources in the Mekong delta floodplains: arsenic and other trace metals pose serious health risks to population. Environment International 34 (6), 756-764. https://doi.org/10.1016/j.envint.2007.12.025.

Chakraborti, D. (2016). Is WHO guideline value of arsenic in drinking water $10 \mathrm{ppb}$ in the developing countries safe to drink? BLDE University Journal of Health Sciences 1 (1), 57. https://doi.org/10.4103/2456-1975. 183289. 
Chakraborti, D./Das, B./Rahman, M. M./Chowdhury, U. K./Biswas, B./Goswami, A. B./Nayak, B./Pal, A./Sengupta, M. K./Ahamed, S./Hossain, A./Basu, G./Roychowdhury, T./Das, D. (2009). Status of groundwater arsenic contamination in the state of West Bengal, India: a 20-year study report. Molecular Nutrition \& Food Research 53 (5), 542-551. https://doi.org/10.1002/mnfr.200700517.

Chakraborti, D./Mukherjee, S. C./Pati, S./Sengupta, M. K./Rahman, M. M./Chowdhury, U. K./Lodh, D./Chanda, C. R./Chakraborti, A. K./Basu, G. K. (2003). Arsenic groundwater contamination in Middle Ganga Plain, Bihar, India: a future danger? Environmental Health Perspectives 111 (9), 1194-1201. https://doi.org/10.1289/ehp.5966.

Chakraborti, D./Paul, K./Chowdhury, U. K./Lodh, D./Chanda, C. R./Saha, K. C. (2002). Arsenic calamity in the Indian subcontinent. what lessons have been learned? Talanta 58 (1), 3-22. https://doi.org/10.1016/ s0039-9140(02)00270-9.

Chakraborti, D./Rahman, M. M./Das, B./Murrill, M./Dey, S./Chandra Mukherjee, S./Dhar, R. K./Biswas, B. K./Chowdhury, U. K./Roy, S./Sorif, S./Selim, M./Rahman, M./Quamruzzaman, Q. (2010). Status of groundwater arsenic contamination in Bangladesh: a 14year study report. Water Research 44 (19), 5789-5802. https://doi.org/10.1016/j.watres.2010.06.051.

Chakraborti, D./Sengupta, M. K./Rahman, M. M./Ahamed, S./Chowdhury, U. K./Hossain, M. A./Mukherjee, S. C./Pati, S./Saha, K. C./Dutta, R. N./Quamruzzaman, Q. (2004). Groundwater arsenic contamination and its health effects in the Ganga-MeghnaBrahmaputra plain. Journal of Environmental Monitoring: JEM 6 (6), $74 \mathrm{~N}-83 \mathrm{~N}$.

Chakraborti, D./Singh, S. K./Rahman, M. M./Dutta, R. N./Mukherjee, S. C./Pati, S./Kar, P. B. (2018). Groundwater arsenic contamination in the Ganga River Basin: a future health danger. International Journal of Environmental Research and Public Health 15 (2). https://doi.org/10.3390/ijerph15020180.

Chatterjee, A./Mukherjee, A. (1999). Hydrogeological investigation of ground water arsenic contamination in South Calcutta. The Science of the Total Environment 225 (3), 249-262. https://doi.org/10.1016/s00489697(98)00367-2.

Chattopadhyay, B. P./Mukherjee, A. K./Gangopadhyay P. K./Alam, J./Roychowdhury, A. (2010). Respiratory effect related to exposure of different concentrations of arsenic in drinking water in West Bengal, India. Journal of Environmental Science and Engineering 52, 147-154.

Chauhan, V. S./Yunus, M./Sankararamakrishnan, N. (2012). Geochemistry and mobilization of arsenic in Shuklaganj area of Kanpur-Unnao district, Uttar Pradesh, India. Environmental Monitoring and Assessment 184 (8), 4889-4901. https://doi.org/10.1007/s10661011-2310-5.
Chen, C.-J./Chen, S.-Y./Chen, C.-L./Chen, C.-Y./Cheng, Y.-C./Chiou, H.-Y./Chou, W.-L./Hsu, L.-I./Hsu, Y.H./Hsueh, Y.-M./Lee, C.-Y./Lin, Y.-C./Shih, W.-L./Tseng, M.-P./Wang, Y.-H./Wang, L.-H./Wang, C.-H./Wu, M.-M. (2005). Biomarkers of exposure, effect, and susceptibility of arsenic-induced health hazards in Taiwan. Toxicology and Applied Pharmacology 206 (2), 198-206. https://doi.org/10.1016/j.taap.2004.10.023.

Chen, Y./Ahsan, H. (2004). Cancer burden from arsenic in drinking water in Bangladesh. American Journal of Public Health 94 (5), 741-744. https://doi.org/10.2105/ajph.94.5.741.

Chen, Y./Parvez, F./Gamble, M./Islam, T./Ahmed, A./Argos, M./Graziano, J. H./Ahsan, H. (2009). Arsenic exposure at low-to-moderate levels and skin lesions, arsenic metabolism, neurological functions, and biomarkers for respiratory and cardiovascular diseases: review of recent findings from the health effects of arsenic longitudinal study (HEALS) in Bangladesh. Toxicology and Applied Pharmacology 239 (2), 184-192. https://doi.org/10.1016/j.taap.2009.01.010.

Chowdhury, U. K./Biswas, B. K./Chowdhury, T. R./Samanta, G./Mandal, B. K./Basu, G. C./Chanda, C. R./Lodh, D./Saha, K. C./Mukherjee, S. K./Roy, S./Kabir, S./Quamruzzaman, Q./Chakraborti, D. (2000). Groundwater arsenic contamination in Bangladesh and West Bengal, India. Environmental Health Perspectives 108 (5), 393-397. https://doi.org/10.1289/ehp.00108393.

Cohen, S. M./Arnold, L. L./Eldan, M./Lewis, A. S./Beck, B. D. (2006). Methylated arsenicals: the implications of metabolism and carcinogenicity studies in rodents to human risk assessment. Critical Reviews in Toxicology 36 (2), 99-133. https://doi.org/10.1080/10408440500534230.

Costa, M. (2019). Review of arsenic toxicity, speciation and polyadenylation of canonical histones. Toxicology and Applied Pharmacology 375, 1-4. https://doi.org/10.1016/j.taap.2019.05.006.

Das, D./Chatterjee, A./Mandal, B. K./Samanta, G./Chakraborti, D./Chanda, B. (1995). Arsenic in ground water in six districts of West bengal, India: the biggest arsenic calamity in the world. Part 2. Arsenic concentration in drinking water, hair, nails, urine, skin-scale and liver tissue (biopsy) of the affected people. The Analyst 120 (3), 917-924. https://doi.org/10.1039/an9952000917.

Das, D./Chatterjee, A./Samanta, G./Mandal, B./Chowdhury, T. R./Chowdhury, P. P./Chanda, C./Basu, G./Lodh, D. (1994). Arsenic contamination in groundwater in six districts of West Bengal, India: the biggest arsenic calamity in the world. The Analyst 119 (12), 168N-170N. https://doi.org/10.1039/an994190168n.

Deb, D./Biswas, A./Ghose, A./Das, A./Majumdar, K. K./Guha Mazumder, D. N. (2013). Nutritional deficiency and arsenical manifestations: a perspective study in an arsenic-endemic region of West Bengal, India. Public Health Nutrition 16 (9), 1644-1655. https://doi.org/10.1017/S1368980012004697. 
Deuel, L. E./Swoboda, A. R. (1972). Arsenic toxicity to cotton and soybeans. Journal of Environmental Quality 1 (3), 317-320. https://doi.org/10.2134/jeq1972.00472425000100030026x.

Dhar, R. K./Biswas, B. K./Samanta, G./Mandal, B. K./Roychowdhury, T./Chanda, C. R./Basu, G./Chakraborti, D./Roy, S./Kabir, S./Zafar, A./Faruk, I./Islam, K. S./Choudhury, M./Arif, A. I. (1998). Groundwater arsenic contamination and suffering of people in Bangladesh may be the biggest arsenic calamity in the world. In: International conference on arsenic pollution of groundwater in Bangladesh. Causes, Effects and Remedies; Dhaka, Bangladesh, Feb. 8-12, 1998, 86-87.

Dittmar, J./Voegelin, A./Roberts, L. C./Hug, S. J./Saha, G. C./Ali, M. A./Badruzzaman, A. B. M./Kretzschmar, R. (2010). Arsenic accumulation in a paddy field in Bangladesh: seasonal dynamics and trends over a three-year monitoring period. Environmental Science \& Technology 44 (8), 2925-2931. https://doi.org/10.1021/es903117r.

Ehrenstein, O. S. von/Poddar, S./Yuan, Y./Mazumder, D. G./Eskenazi, B./Basu, A./Hira-Smith, M./Ghosh, N./Lahiri, S./Haque, R./Ghosh, A./Kalman, D./Das, S./Smith, A. H. (2007). Children's intellectual function in relation to arsenic exposure. Epidemiology 18 (1), 44-51. https://doi.org/10.1097/01.ede.0000248900.65613.a9.

Fatmi, Z./Azam, I./Ahmed, F./Kazi, A./Gill, A. B./Kadir, M. M./Ahmed, M./Ara, N./Janjua, N. Z. (2009). Health burden of skin lesions at low arsenic exposure through groundwater in Pakistan. Is river the source? Environmental Research 109 (5), 575-581. https://doi.org/10.1016/j.envres.2009.04.002.

Fazal, M. A./Kawachi, T./Ichion, E. (2001). Extent and severity of groundwater arsenic contamination in Bangladesh. Water International 26 (3), 370-379. https://doi.org/10.1080/02508060108686929.

Ferguson, J. F./Gavis, J. (1972). A review of the arsenic cycle in natural waters. Water Research 6 (11), 1259-1274.

Gambrell, R. P./Patrick, W. H. (1989). Cu, Zn, and Cd availability in a sludge-amended soil under controlled $\mathrm{pH}$ and redox potential conditions. In: W. D. Billings/F. Golley/O. L. Lange et al. (Eds.). Inorganic Contaminants in the Vadose Zone. Berlin, Heidelberg, Springer, 89-106.

Garelick, H./Jones, H./Dybowska, A./Valsami-Jones, E. (2008). Arsenic pollution sources. Reviews of Environmental Contamination and Toxicology 197, 17-60. https://doi.org/10.1007/978-0-387-79284-2_2.

Gault, A. G./Rowland, H. A. L./Charnock, J. M./Wogelius, R. A./Gomez-Morilla, I./Vong, S./Leng, M./Samreth, S./Sampson, M. L./Polya, D. A. (2008). Arsenic in hair and nails of individuals exposed to arsenic-rich groundwaters in Kandal province, Cambodia. The Science of the Total Environment 393 (1), 168-176. https://doi.org/10.1016/j.scitotenv.2007.12.028.
George, C. M./Factor-Litvak, P./Khan, K./Islam, T./Singha, A./Moon-Howard, J./van Geen, A./Graziano, J. H. (2013). Approaches to increase arsenic awareness in Bangladesh: an evaluation of an arsenic education program. Health Education \& Behavior : The Official Publication of the Society for Public Health Education 40 (3), 331-338. https://doi.org/10.1177/1090198112454735.

Ghosh, P./Banerjee, M./Chaudhuri, S. de/Chowdhury, R./Das, J. K./Mukherjee, A./Sarkar, A. K./Mondal, L./Baidya, K./Sau, T. J./Banerjee, A./Basu, A./Chaudhuri, K./Ray, K./Giri, A. K. (2007). Comparison of health effects between individuals with and without skin lesions in the population exposed to arsenic through drinking water in West Bengal, India. Journal of Exposure Science \& Environmental Epidemiology 17 (3), 215-223. https://doi.org/10.1038/sj.jes.7500510.

Ghosh, P./Roy, C./Das, N. K./Sengupta, S. R. (2008). Epidemiology and prevention of chronic arsenicosis: an Indian perspective. Indian Journal of Dermatology, Venereology and Leprology 74 (6), 582-593. https://doi. org/10.4103/0378-6323.45099.

Goodenough, W. H. (1963). Cooperation in change. an anthropological approach to community development. New York, Russell Sage Foundation.

Goswami, R./Kumar, M./Biyani, N./Shea, P. J. (2020). Arsenic exposure and perception of health risk due to groundwater contamination in Majuli (river island), Assam, India. Environmental Geochemistry and Health 42 (2), 443-460. https://doi.org/10.1007/s10653-01900373-9.

Grantham, D. A./Jones, J. F. (1977). Arsenic contamination of water wells in Nova Scotia. Journal - American Water Works Association 69 (12), 653-657. https://doi. org/10.1002/j.1551-8833.1977.tb06844.x.

Guha Mazumder, D. N./Haque, R./Ghosh, N./De, B. K./Santra, A./Chakraborty, D./Smith, A. H. (1998). Arsenic levels in drinking water and the prevalence of skin lesions in West Bengal, India. International Journal of Epidemiology 27 (5), 871-877. https://doi.org/10.1093/ije/27.5.871.

Guha Mazumder, D./Dasgupta, U. B. (2011). Chronic arsenic toxicity: studies in West Bengal, India. The Kaohsiung Journal of Medical Sciences 27 (9), 360-370. https://doi.org/10.1016/j.kjms.2011.05.003.

Gulledge, J. H./O’Connor, J. T. (1973). Removal of arsenic (V) from water by adsorption on aluminum and ferric hydroxides. Journal - American Water Works Association 65 (8), 548-552. https://doi.org/10.1002/j. 1551-8833.1973.tb01893.x.

Guo, X./Fujino, Y./Kaneko, S./Wu, K./Xia, Y./Yoshimura, T. (2001). Arsenic contamination of groundwater and prevalence of arsenical dermatosis in the Hetao plain area, Inner Mongolia, China. Molecular and Cellular Biochemistry 222 (1-2), 137-140. 
Hadi, A. (2003). Fighting arsenic at the grassroots: experience of BRAC's community awareness initiative in Bangladesh. Health Policy and Planning 18 (1), 93-100. https://doi.org/10.1093/heapol/18.1.93.

Halim, M. A./Majumder, R. K./Nessa, S. A./Oda, K./Hiroshiro, Y./Jinno, K. (2010). Arsenic in shallow aquifer in the eastern region of Bangladesh: insights from principal component analysis of groundwater compositions. Environmental Monitoring and Assessment 161 (1-4), 453-472. https://doi.org/10.1007/s10661-009-0760-9.

Hall, M./Chen, Y./Ahsan, H./Slavkovich, V./van Geen, A./Parvez, F./Graziano, J. (2006). Blood arsenic as a biomarker of arsenic exposure: results from a prospective study. Toxicology 225 (2-3), 225-233. https://doi.org/10.1016/j.tox.2006.06.010.

Hanchett, S./Nahar, Q./van Agthoven, A./Geers, C./Rezvi, M. D. F. J. (2002). Increasing awareness of arsenic in Bangladesh: lessons from a public education programme. Health Policy and Planning 17 (4), 393-401. https://doi.org/10.1093/heapol/17.4.393.

Hanh, H. T./Kim, K.-W./Bang, S./Hoa, N. M. (2011). Community exposure to arsenic in the Mekong river delta, Southern Vietnam. Journal of Environmental Monitoring: JEM 13 (7), 2025-2032. https://doi.org/10.1039/C1EM10037H.

Harvey, C. F./Swartz, C. H./Badruzzaman, A. B. M./Keon-Blute, N./Yu, W./Ali, M. A./Jay, J./Beckie, R./Niedan, V./Brabander, D./Oates, P. M./Ashfaque, K. N./Islam, S./Hemond, H. F./Ahmed, M. F. (2002). Arsenic mobility and groundwater extraction in Bangladesh. Science 298 (5598), 1602-1606. https://doi.org/10.1126/science.1076978.

Hassan, M. M./Atkins, P. J./Dunn, C. E. (2005). Social implications of arsenic poisoning in Bangladesh. Social Science \& Medicine 61 (10), 2201-2211. https://doi.org/10.1016/j.socscimed.2005.04.021.

Hayat, E./Baba, A. (2017). Quality of groundwater resources in Afghanistan. Environmental Monitoring and Assessment 189 (7), 318. https://doi.org/10.1007/s10661017-6032-1.

He, W./Greenwell, R. J./Brooks, D. M./Calderón-Garcidueñas, L./Beall, H. D./Coffin, J. D. (2007). Arsenic exposure in pregnant mice disrupts placental vasculogenesis and causes spontaneous abortion. Toxicological Sciences : An Official Journal of the Society of Toxicology 99 (1), 244-253. https://doi.org/10.1093/toxsci/kfm162.

Heijnen, H. (2003). Criteria for selection of technologies for arsenic mitigation. In: M. F. Ahmed (Ed.). Arsenic contamination. Bangladesh perspective. Dhaka, ITNBangladesh, Centre for Water Supply and Waste Management, 429-441.
Hoque, B. A./Hoque, M. M./Ahmed, T./Islam, S./Azad, A. K./Ali, N./Hossain, M./Hossain, M. S. (2004). Demand-based water options for arsenic mitigation: an experience from rural Bangladesh. Public Health 118 (1), 70-77. https://doi.org/10.1016/s0033-3506(03)00135-5.

Hossain, M. F. (2006). Arsenic contamination in Bangladesh-an overview. Agriculture, Ecosystems \& Environment 113 (1-4), 1-16. https://doi.org/10.1016/j.agee.2005.08.034.

Hughes, M. F. (2006). Biomarkers of exposure: a case study with inorganic arsenic. Environmental Health Perspectives 114 (11), 1790-1796. https://doi.org/10.1289/ehp.9058.

Hutchinson, J. (1888). On some examples of arsenickeratosis of the skin and of arsenic-cancer. Transactions of the Pathological Society of London 39, 352-363.

Huyck, K. L./Kile, M. L./Mahiuddin, G./Quamruzzaman, Q./Rahman, M./Breton, C. V./Dobson, C. B./Frelich, J./Hoffman, E./Yousuf, J./Afroz, S./Islam, S./Christiani, D. C. (2007). Maternal arsenic exposure associated with low birth weight in Bangladesh. Journal of Occupational and Environmental Medicine 49 (10), 1097-1104. https://doi.org/10.1097/jom.0b013e3181566ba0.

Huysmans, K. D./Frankenberger, W. T. (1990). Arsenic resistant microorganisms isolated from agricultural drainage water and evaporation pond sediments. Water, Air, and Soil Pollution 53 (1-2), 159-168. https://doi.org/10.1007/BF00155000.

IARC (1980). Some metals and metallic compounds. An IARC working group on the evaluation of the carcinogenic risk of chemicals to humans which met in Lyon, 23 - 30 October 1979. Lyon, International Agency for Research on Cancer.

Inauen, J./Tobias, R./Mosler, H.-J. (2013). Predicting water consumption habits for seven arsenic-safe water options in Bangladesh. BMC Public Health 13, 417. https://doi.org/10.1186/1471-2458-13-417.

Jain, C. K. (2002). Arsenic contamination in ground water: Indian scenario. Indian Journal of Environmental Health 44 (3), 238-243.

Järup, L./Pershagen, G./Wall, S. (1989). Cumulative arsenic exposure and lung cancer in smelter workers: a dose-response study. American Journal of Industrial Medicine 15 (1), 31-41. https://doi.org/10.1002/ajim.4700150105.

Khalequzzaman, M./Faruque, F. S./Mitra, A. K. (2005). Assessment of arsenic contamination of groundwater and health problems in Bangladesh. International Journal of Environmental Research and Public Health 2 (2), 204-213. https://doi.org/10.3390/ijerph2005020002. 
Khan, M. M. H./Sakauchi, F./Sonoda, T./Washio, M./Mori, M. (2003). Magnitude of arsenic toxicity in tube-well drinking water in Bangladesh and its adverse effects on human health including cancer: evidence from a review of the literature. Asian Economic Journal $4(1), 7-14$

Kile, M. L./Cardenas, A./Rodrigues, E./Mazumdar, M./Dobson, C./Golam, M./Quamruzzaman, Q./Rahman, M./Christiani, D. C. (2016). Estimating effects of arsenic exposure during pregnancy on perinatal outcomes in a Bangladeshi cohort. Epidemiology 27 (2), 173-181. https://doi.org/10.1097/ede.0000000000000416.

Kim, K.-W./Chanpiwat, P./Hanh, H. T./Phan, K./Sthiannopkao, S. (2011). Arsenic geochemistry of groundwater in Southeast Asia. Frontiers of Medicine 5 (4), 420-433. https://doi.org/10.1007/s11684-011-0158-2.

Kwok, R. K./Kaufmann, R. B./Jakariya, M. (2006). Arsenic in drinking-water and reproductive health outcomes: a study of participants in the Bangladesh integrated nutrition programme. Journal of Health, Population and Nutrition 24 (2), 190-205.

Lacasa, E./Cañizares, P./Sáez, C./Fernández, F. J./Rodrigo, M. A. (2011). Removal of arsenic by iron and aluminium electrochemically assisted coagulation. Separation and Purification Technology 79 (1), 15-19. https://doi.org/10.1016/j.seppur.2011.03.005.

Le Luu, T. (2019). Remarks on the current quality of groundwater in Vietnam. Environmental Science and Pollution Research International 26 (2), 1163-1169. https://doi.org/10.1007/s11356-017-9631-z.

Mahata, J./Basu, A./Ghoshal, S./Sarkar, J. N./Roy, A. K./Poddar, G./Nandy, A. K./Banerjee, A./Ray, K./Natarajan, A. T./Nilsson, R./Giri, A. K. (2003). Chromosomal aberrations and sister chromatid exchanges in individuals exposed to arsenic through drinking water in West Bengal, India. Mutation Research/Genetic Toxicology and Environmental Mutagenesis 534 (1-2), 133-143. https://doi.org/10.1016/s1383-5718(02)00255-3.

Mandal, B. K./Chowdhury, T. R./Samanta, G./Mukherjee, D. P./Chanda, C. R./Saha, K. C./Chakraborti, D. (1998). Impact of safe water for drinking and cooking on five arsenic-affected families for 2 years in West Bengal, India. The Science of the Total Environment 218 (2-3), 185-201. https://doi.org/10.1016/s0048-9697(98)00220-4.

Mandal, B. K./Ogra, Y./Anzai, K./Suzuki, K. T. (2004). Speciation of arsenic in biological samples. Toxicology and Applied Pharmacology 198 (3), 307-318. https://doi.org/10.1016/j.taap.2003.10.030.

Mayer, J. E./Goldman, R. H. (2016). Arsenic and skin cancer in the USA: the current evidence regarding arsenic-contaminated drinking water. International Journal of Dermatology 55 (11), e585-e591. https://doi.org/10.1111/ijd.13318.
McArthur, J. M./Ravenscroft, P./Safiulla, S./Thirlwall, M. F. (2001). Arsenic in groundwater: testing pollution mechanisms for sedimentary aquifers in Bangladesh. Water Resources Research 37 (1), 109-117. https://doi.org/10.1029/2000WR900270.

Meharg, A. A./Rahman, M. (2003). Arsenic contamination of Bangladesh paddy field soils: implications for rice contribution to arsenic consumption. Environmental Science \& Technology 37 (2), 229-234. https://doi.org/10.1021/es0259842.

Melkonian, S./Argos, M./Chen, Y./Parvez, F./Pierce, B./Ahmed, A./Islam, T./Ahsan, H. (2012). Intakes of several nutrients are associated with incidence of arsenic-related keratotic skin lesions in Bangladesh. The Journal of Nutrition 142 (12), 2128-2134. https://doi.org/10.3945/jn.112.165720.

Milton, A. H./Smith, W./Rahman, B./Hasan, Z./Kulsum, U./Dear, K./Rakibuddin, M./Ali, A. (2005). Chronic arsenic exposure and adverse pregnancy outcomes in Bangladesh. Epidemiology 16 (1), 82-86. https://doi.org/10.1097/01.ede.0000147105.94041.e6.

Mohan, D./Pittman, C. U. (2007). Arsenic removal from water/wastewater using adsorbents-a critical review. Journal of Hazardous Materials 142 (1-2), 1-53. https://doi.org/10.1016/j.jhazmat.2007.01.006.

Moore, J. N./Ficklin, W. H./Johns, C. (1988). Partitioning of arsenic and metals in reducing sulfidic sediments. Environmental Science \& Technology 22 (4), 432-437. https://doi.org/10.1021/es00169a011.

Mosler, H.-J./Blöchliger, O. R./Inauen, J. (2010). Personal, social, and situational factors influencing the consumption of drinking water from arsenic-safe deep tubewells in Bangladesh. Journal of Environmental Management 91 (6), 1316-1323. https://doi.org/10.1016/j.jenvman.2010.02.012.

Mueller, B. (2017). Arsenic in groundwater in the southern lowlands of Nepal and its mitigation options: a review. Environmental Reviews 25 (3), 296-305. https:// doi.org/10.1139/er-2016-0068.

Mukherjee, A. B./Bhattacharya, P. (2001). Arsenic in groundwater in the Bengal Delta Plain: slow poisoning in Bangladesh. Environmental Reviews 9 (3), 189-220. https://doi.org/10.1139/er-9-3-189.

Mukherjee, A./Bhattacharya, P./Savage, K./Foster, A./Bundschuh, J. (2008). Distribution of geogenic arsenic in hydrologic systems: controls and challenges. Journal of Contaminant Hydrology 99 (1-4), 1-7. https://doi.org/10.1016/j.jconhyd.2008.04.002.

Mukherjee, A./Sengupta, M. K./Hossain, M. A./Ahamed, S./Das, B./Nayak, B./Lodh, D./Rahman, M. M./Chakraborti, D. (2006). Arsenic contamination in groundwater: a global perspective with emphasis on the Asian scenario. Journal of Health, Population, and Nutrition 24 (2), 142-163. 
Mukherjee, S. C./Rahman, M. M./Chowdhury, U. K./Sengupta, M. K./Lodh, D./Chanda, C. R./Saha, K. C./Chakraborti, D. (2003). Neuropathy in arsenic toxicity from groundwater arsenic contamination in West Bengal, India. Journal of Environmental Science and Health. Part A, Toxic/Hazardous Substances \& Environmental Engineering 38 (1), 165-183. https://doi.org/10.1081/ ese-120016887.

Mukherjee, S. C./Saha, K. C./Pati, S./Dutta, R. N./Rahman, M. M./Sengupta, M. K./Ahamed, S./Lodh, D./Das, B./Hossain, M. A./Nayak, B./Mukherjee, A./Chakraborti, D./Dulta, S. K./Palit, S. K./Kaies, I./Barua, A. K./Asad, K. A. (2005). Murshidabad one of the nine groundwater arsenic-affected districts of West Bengal, India. Part II: dermatological, neurological, and obstetric findings. Clinical toxicology (Philadelphia, Pa.) 43 (7), 835-848. https://doi.org/10.1080/15563650500357495.

Murphy, T./Phan, K./Yumvihoze, E./Irvine, K./Wilson, K./Lean, D./Ty, B./Poulain, A./Laird, B./Chan, L. H. M. (2018). Groundwater irrigation and arsenic speciation in rice in Cambodia. Journal of Health \& Pollution 8 (19), 180911. https://doi.org/10.5696/2156-9614-8.19.180911.

Nahar, N./Hossain, F./Hossain, M. D. (2008). Health and socioeconomic effects of groundwater arsenic contamination in rural Bangladesh: new evidence from field surveys. Journal of environmental health 70 (9), 42-47.

Naujokas, M. F./Anderson, B./Ahsan, H./Aposhian, H. V./Graziano, J. H./Thompson, C./Suk, W. A. (2013). The broad scope of health effects from chronic arsenic exposure: update on a worldwide public health problem. Environmental Health Perspectives 121 (3), 295-302. https://doi.org/10.1289/ehp.1205875.

Nelson, Katie/Braff, Lara/Shook, Beth/Aguilera, Kelsie (2019). Introduction to Biological Anthropology. In: Beth Shook/Katie Nelson/Kelsie Aguilera et al. (Eds.). Explorations. An open invitation to biological anthropology. Arlington, VA, American Anthropological Association.

Nickson, R./McArthur, J./Burgess, W./Ahmed, K. M./Ravenscroft, P./Rahman, M. (1998). Arsenic poisoning of Bangladesh groundwater. Nature 395 (6700), 338. https://doi.org/10.1038/26387.

Pacyna, J. M. (1987). Atmospheric emissions of arsenic, cadmium, lead and mercury from high temperature processes in power generation and industry. Scientific Committee on Problems of the Environment (SCOPE) (31), 69-87. Available online at https://scope. dge.carnegiescience.edu/SCOPE_31/SCOPE_31_2. 02_Chapter7_69-87.pdf.

Palermo, M. R./Shafer, R. A./Brannon, J. M./Myers, T. E./Truitt, C. L./Zappi, M. E. (1989). Evaluation of dredged material disposal alternatives for US Navy Homeport at Everett, Washington. Vicksburg, Miss., US Army Eng. Waterways Exp. Lab.
Pandey, P. K./Sharma, R./Roy, M./Roy, S./Pandey, M. (2006). Arsenic contamination in the Kanker district of central-east India: geology and health effects. Environmental Geochemistry and Health 28 (5), 409-420. https://doi.org/10.1007/s10653-005-9039-4.

Pandey, P. K./Yadav, S./Pandey, M. (2007). Human arsenic poisoning issues in central-east Indian locations: biomarkers and biochemical monitoring. International Journal of Environmental Research and Public Health 4 (1), 15-22. https://doi.org/10.3390/ijerph2007010003.

Parvez, F./Chen, Y./Argos, M./Hussain, A.Z.M. I/Momotaj, H./Dhar, R./van Geen, A./Graziano, J. H./Ahsan, H. (2006). Prevalence of arsenic exposure from drinking water and awareness of its health risks in a Bangladeshi population: results from a large population-based study. Environmental Health Perspectives 114 (3), 355-359. https://doi.org/10.1289/ehp.7903.

Paul, B. K. (2004). Arsenic contamination awareness among the rural residents in Bangladesh. Social Science \& Medicine 59 (8), 1741-1755. https://doi.org/10.1016/j.socscimed.2004.01.037.

Pershagen, G. (1981). The carcinogenicity of arsenic. Environmental Health Perspectives 40, 93-100. https://doi.org/10.1289/ehp.814093.

Pontius, F. W./Brown, K. G./Chen, C.-J. (1994). Health implications of arsenic in drinking water. Journal American Water Works Association 86 (9), 52-63. https://doi.org/10.1002/j.1551-8833.1994.tb06246.x.

Rahaman, S./Sinha, A. C./Pati, R./Mukhopadhyay, D. (2013). Arsenic contamination: a potential hazard to the affected areas of West Bengal, India. Environmental Geochemistry and Health 35 (1), 119-132. https://doi. org/10.1007/s10653-012-9460-4.

Rahman, M. M./Mandal, B. K./Chowdhury, T. R./Sengupta, M. K./Chowdhury, U. K./Lodh, D./Chanda, C. R./Basu, G. K./Mukherjee, S. C./Saha, K. C./Chakraborti, D. (2003). Arsenic groundwater contamination and sufferings of people in North 24-Parganas, one of the nine arsenic affected districts of West Bengal, India. Journal of Environmental Science and Health. Part A, Toxic/Hazardous Substances \& Environmental Engineering 38 (1), 25-59. https://doi.org/10.1081/ ese-120016658.

Rahman, M./Sohel, N./Yunus, F. M./Alam, N./Nahar, Q./Streatfield, P. K./Yunus, M. (2019). Arsenic exposure and young adult's mortality risk: a 13-year followup study in Matlab, Bangladesh. Environment International 123, 358-367. https://doi.org/10.1016/j.envint.2018.12.006.

Ravenscroft, P./Brammer, H./Richards, K. S. (2009). Arsenic pollution. a global synthesis. Chichester, U.K./Malden, MA, Wiley-Blackwell. 
Rivera-Núñez, Z./Meliker, J. R./Linder, A. M./Nriagu, J. O. (2010). Reliability of spot urine samples in assessing arsenic exposure. International Journal of Hygiene and Environmental Health 213 (4), 259-264. https://doi.org/10.1016/j.ijheh.2010.03.003.

Rockett, J. C./Kim, S. J. (2005). Biomarkers of reproductive toxicity. Cancer Biomarkers : Section A of Disease Markers 1 (1), 93-108. https://doi.org/10.3233/ cbm-2005-1110.

Rowland, H. A. L./Boothman, C./Pancost, R./Gault, A. G./Polya, D. A./Lloyd, J. R. (2009). The role of indigenous microorganisms in the biodegradation of naturally occurring petroleum, the reduction of iron, and the mobilization of arsenite from West Bengal aquifer sediments. Journal of Environmental Quality 38 (4), 1598-1607. https://doi.org/10.2134/jeq2008.0223.

Roychowdhury, T. (2008). Impact of sedimentary arsenic through irrigated groundwater on soil, plant, crops and human continuum from Bengal delta: special reference to raw and cooked rice. Food and Chemical Toxicology : An International Journal Published for the British Industrial Biological Research Association 46 (8), 2856-2864. https://doi.org/10.1016/j.fct.2008.05.019.

Roychowdhury, T./Uchino, T./Tokunaga, H. (2008). Effect of arsenic on soil, plant and foodstuffs by using irrigated groundwater and pond water from Nadia district, West Bengal. International Journal of Environment and Pollution 33 (2/3), 218. https://doi.org/10.1504/IJEP.2008.019395.

Roychowdhury, T./Uchino, T./Tokunaga, H./Ando, M. (2002a). Arsenic and other heavy metals in soils from an arsenic-affected area of West Bengal, India. Chemosphere 49 (6), 605-618. https://doi.org/10.1016/ s0045-6535(02)00309-0.

Roychowdhury, T./Uchino, T./Tokunaga, H./Ando, M. (2002b). Survey of arsenic in food composites from an arsenic-affected area of West Bengal, India. Food and Chemical Toxicology : An International Journal Published for the British Industrial Biological Research Association 40 (11), 1611-1621. https://doi.org/10.1016/ s0278-6915(02)00104-7.

Ruiz de Luzuriaga, A. M./Ahsan, H./Shea, C. R. (2011). Arsenical keratoses in Bangladesh-update and prevention strategies. Dermatologic Clinics 29 (1), 45-51. https://doi.org/10.1016/j.det.2010.09.003.

Saint-Jacques, N./Brown, P./Nauta, L./Boxall, J./Parker, L./Dummer, T. J. B. (2018). Estimating the risk of bladder and kidney cancer from exposure to lowlevels of arsenic in drinking water, Nova Scotia, Canada. Environment International 110, 95-104. https://doi.org/10.1016/j.envint.2017.10.014.

Samal, A. C./Kar, S./Bhattacharya, P./Santra, S. C. (2011). Human exposure to arsenic through foodstuffs cultivated using arsenic contaminated groundwater in areas of West Bengal, India. Journal of Environmental Science and Health. Part A, Toxic/Hazardous Substances \& Environmental Engineering 46 (11), 1259-1265. https://doi.org/10.1080/10934529.2011.598810.
Samanta, G./Das, D./Mandal, B. K./Chowdhury, T. R./Chakraborti, D./Pal, A./Ahamed, S. (2007). Arsenic in the breast milk of lactating women in arsenic-affected areas of West Bengal, India and its effect on infants. Journal of Environmental Science and Health. Part A, Toxic/Hazardous Substances \& Environmental Engineering 42 (12), 1815-1825. https://doi.org/10.1080/10934520701566785.

Sanjrani, M. A./Zhou, B./Zhao, H./Bhutto, S. U./Muneer, A. S./Xia, S. B. (2019). Arsenic contaminated groundwater in China and its treatment options, a review. Applied Ecology and Environmental Research 17 (2), 1655-1683. https://doi.org/10.15666/aeer/1702_16551683.

Sarifuzzaman, M./Siddique, M. N. A./Ferdousi, F. K./Ahmed, E./Alam, A. M. S./Ullah, S. M. (2007). Studies of arsenic mobilization with iron, manganese and copper in borehole sediments of the river Padma.

Sarkar, A./Mehrotra, R. (2005). Social dimensions of chronic arsenicosis in West Bengal (India). Epidemiology 16 (5), S68. https://doi.org/10.1097/00001648200509000-00165.

Sarkar, S./Greenleaf, J. E./Gupta, A./Ghosh, D./Blaney, L. M./Bandyopadhyay, P./Biswas, R. K./Dutta, A. K./Sengupta, A. K. (2010). Evolution of community-based arsenic removal systems in remote villages in West Bengal, India: assessment of decade-long operation. Water Research 44 (19), 5813-5822. https://doi.org/10.1016/j.watres.2010.07.072.

Sarker, M. M. R. (2010). Determinants of arsenicosis patients' perception and social implications of arsenic poisoning through groundwater in Bangladesh. International Journal of Environmental Research and Public Health 7 (10), 3644-3656. https://doi.org/10.3390/ijerph7103644.

Schell, Lawrence M./Burnitz, Kristopher K./Lathrop, Patrick W. (2010). Pollution and human biology. Annals of Human Biology 37 (3), 347-366. https://doi.org/10.3109/03014461003705511.

Schell, Lawrence M./Denham, Melinda (2003). Environmental pollution in urban environments and human biology. Annual Review of Anthropology 32 (1), 111-134. https://doi.org/10.1146/annurev.anthro.32.061002.093218.

Schell, Lawrence M./Gallo, Mia V./Denham, Melinda/Ravenscroft, Julia (2006). Effects of pollution on human growth and development: an introduction. Journal of Physiological Anthropology 25 (1), 103-112. https://doi.org/10.2114/jpa2.25.103.

Schell, Lawrence M./Gallo, Mia V./Ravenscroft, Julia (2009). Environmental influences on human growth and development: historical review and case study of contemporary influences. Annals of Human Biology 36 (5), 459-477. https://doi.org/10.1080/03014460903067159. 
Schmitt, M. T./Schreinemachers, D./Wu, K./Ning, Z./Zhao, B./Le, X. C./Mumford, J. L. (2005). Human nails as a biomarker of arsenic exposure from well water in Inner Mongolia: comparing atomic fluorescence spectrometry and neutron activation analysis. Biomarkers: Biochemical Indicators of Exposure, Response, and Susceptibility to Chemicals 10 (2-3), 95-104. https://doi.org/10.1080/13547500500087913.

Sen, J./Chaudhuri, A. B. D. (2007). Effect of arsenic on the onset of menarcheal age. Bulletin of Environmental Contamination and Toxicology 79 (3), 293-296. https:// doi.org/10.1007/s00128-007-9206-7.

Sen, J./Chaudhuri, A. B. D. (2008). Arsenic exposure through drinking water and its effect on pregnancy outcome in Bengali women. Arhiv za higijenu rada i toksikologiju 59 (4), 271-275. https://doi.org/10.2478/ 10004-1254-59-2008-1871.

Shaikh, F. H./Syed, A. S./Rehman, A. (2018). Groundwater contamination and the risk of arsenic poisoning in Pakistan. JPMA. The Journal of the Pakistan Medical Association 68 (8), 1288.

Shankar, S./Shanker, U./Shikha (2014). Arsenic contamination of groundwater: a review of sources, prevalence, health risks, and strategies for mitigation. The Scientific World Journal 2014. https://doi.org/10.1155/2014/304524.

Sharma, A./Flora, S. J. S. (2018). Nutritional management can assist a significant role in alleviation of arsenicosis. Journal of trace elements in medicine and biology : organ of the Society for Minerals and Trace Elements (GMS) 45, 11-20. https://doi.org/10.1016/j.jtemb.2017.09.010.

Shih, Y.-H./Scannell Bryan, M./Argos, M. (2020). Association between prenatal arsenic exposure, birth outcomes, and pregnancy complications: An observational study within the National Children's Study cohort. Environmental Research 183, 109182. https://doi.org/10.1016/j.envres.2020.109182.

Shrestha, R. R./Shrestha, M. P./Upadhyay, N. P./Pradhan, R./Khadka, R./Maskey, A./Maharjan, M./Tuladhar, S./Dahal, B. M./Shrestha, K. (2003). Groundwater arsenic contamination, its health impact and mitigation program in Nepal. Journal of Environmental Science and Health. Part A, Toxic/Hazardous Substances \& Environmental Engineering 38 (1), 185-200. https://doi. org/10.1081/ese-120016888.

Shukla, A./Awasthi, S./Chauhan, R./Srivastava, S. (2020). The Status of Arsenic Contamination in India. In: S. Srivastava (Ed.). Arsenic in drinking water and food. Singapore, Springer, 1-12.

Signes-Pastor, A./Burló, F./Mitra, K./Carbonell-Barrachina, A. A. (2007). Arsenic biogeochemistry as affected by phosphorus fertilizer addition, redox potential and $\mathrm{pH}$ in a west Bengal (India) soil. Geoderma 137 (3-4), 504-510. https://doi.org/10.1016/j.geoderma.2006.10.012.
Singh, A. K. (2004). Arsenic Contamination in Groundwater of North Eastern India. In: Proceedings of national seminar on hydrology with the focal theme on "water quality" held at National Institute of Hydrology, Roorkee, Nov 22.-23.

Singh, A. K. (2006). Chemistry of arsenic in groundwater of Ganges-Brahmaputra river basin. Current Science 5 (91), 599-606.

Singh, E. J. K./Gupta, A./Singh, N. R. (2013). Groundwater quality in Imphal West district, Manipur, India, with multivariate statistical analysis of data. Environmental Science and Pollution Research International 20 (4), 2421-2434. https://doi.org/10.1007/s11356-012-1127-2.

Slotnick, M. J./Nriagu, J. O. (2006). Validity of human nails as a biomarker of arsenic and selenium exposure: A review. Environmental Research 102 (1), 125-139. https://doi.org/10.1016/j.envres.2005.12.001.

Smith, A. H./Lingas, E. O./Rahman, M. (2000). Contamination of drinking-water by arsenic in Bangladesh: a public health emergency. Bulletin of the World Health Organization 78 (9), 1093-1103.

Spallholz, J. E./Mallory Boylan, L./Rhaman, M. M. (2004). Environmental hypothesis: is poor dietary selenium intake an underlying factor for arsenicosis and cancer in Bangladesh and West Bengal, India? The Science of the Total Environment 323 (1-3), 21-32. https://doi.org/10.1016/j.scitotenv.2003.09.034.

Steinmaus, C./Carrigan, K./Kalman, D./Atallah, R./Yuan, Y./Smith, A. H. (2005). Dietary intake and arsenic methylation in a U.S. population. Environmental Health Perspectives 113 (9), 1153-1159. https://doi.org/10.1289/ehp.7907.

Stinson, S./Bogin, B./O'Rourke, D. (2012). Human biology. An evolutionary and biocultural perspective. Hoboken, NJ, Wiley.

Stollenwerk, K. G./Breit, G. N./Welch, A. H./Yount, J. C./Whitney, J. W./Foster, A. L./Uddin, M. N./Majumder, R. K./Ahmed, N. (2007). Arsenic attenuation by oxidized aquifer sediments in Bangladesh. The Science of the Total Environment 379 (2-3), 133-150. https://doi.org/10.1016/j.scitotenv.2006.11.029.

Styblo, M./Del Razo, L. M./Vega, L./Germolec, D. R./LeCluyse, E. L./Hamilton, G. A./Reed, W./Wang, C./Cullen, W. R./Thomas, D. J. (2000). Comparative toxicity of trivalent and pentavalent inorganic and methylated arsenicals in rat and human cells. Archives of toxicology 74 (6), 289-299. https://doi.org/10.1007/s002040000134.

Subramanian, K. S./Kosnett, M. J. (1998). Human exposures to arsenic from consumption of well water in West Bengal, India. International journal of occupational and environmental health 4 (4), 217-230. https://doi.org/10.1179/oeh.1998.4.4.217. 
Thakur, B. K./Gupta, V. (2019). Valuing health damages due to groundwater arsenic contamination in Bihar, India. Economics and Human Biology 35, 123-132. https://doi.org/10.1016/j.ehb.2019.06.005.

Tokar, E. J./Diwan, B. A./Waalkes, M. P. (2010). Arsenic exposure transforms human epithelial stem/progenitor cells into a cancer stem-like phenotype. Environmental Health Perspectives 118 (1), 108-115. https://doi.org/10.1289/ehp.0901059.

Tseng, W. P./Chu, H. M./How, S. W./Fong, J. M./Lin, C. S./Yeh, S. (1968). Prevalence of skin cancer in an endemic area of chronic arsenicism in Taiwan. Journal of the National Cancer Institute 40 (3), 453-463.

Vahidnia, A./van der Voet, G. B./Wolff, F. A. de (2007). Arsenic neurotoxicity-a review. Human \& Experimental Toxicology 26 (10), 823-832. https://doi.org/10.1177/0960327107084539.

van Geen, A./Win, K. H./Zaw, T./Naing, W./Mey, J. L./Mailloux, B. (2014). Confirmation of elevated arsenic levels in groundwater of Myanmar. The Science of the Total Environment 478, 21-24. https://doi.org/10.1016/j.scitotenv.2014.01.073.

Visoottiviseth, P./Ahmed, F. (2008). Technology for remediation and disposal of arsenic. Reviews of Environmental Contamination and Toxicology 197, 77-128. https://doi.org/10.1007/978-0-387-79284-2_4.

Vizcaya-Ruiz, A. de/Barbier, O./Ruiz-Ramos, R./Cebrian, M. E. (2009). Biomarkers of oxidative stress and damage in human populations exposed to arsenic. Mutation Research 674 (1-2), 85-92. https://doi.org/10.1016/j.mrgentox.2008.09.020.

Waalkes, M. P./Liu, J./Ward, J. M./Diwan, B. A. (2004). Animal models for arsenic carcinogenesis: inorganic arsenic is a transplacental carcinogen in mice. Toxicology and Applied Pharmacology 198 (3), 377-384. https://doi.org/10.1016/j.taap.2003.10.028.

Wang, G./Fowler, B. A. (2008). Roles of biomarkers in evaluating interactions among mixtures of lead, cadmium and arsenic. Toxicology and Applied Pharmacology 233 (1), 92-99. https://doi.org/10.1016/j.taap.2008.01.017.

Welch, B./Smit, E./Cardenas, A./Hystad, P./Kile, M. L. (2018). Trends in urinary arsenic among the U.S. population by drinking water source: results from the National Health and Nutritional Examinations Survey 2003-2014. Environmental Research 162, 8-17. https://doi.org/10.1016/j.envres.2017.12.012.

Williams, P. N./Islam, S./Islam, R./Jahiruddin, M./Adomako, E./Soliaman, A. R. M./Rahman, G. K. M. M./Lu, Y./Deacon, C./Zhu, Y.-G./Meharg, A. A. (2009). Arsenic limits trace mineral nutrition (selenium, zinc, and nickel) in Bangladesh rice grain. Environmental Science \& Technology 43 (21), 8430-8436. https://doi.org/10.1021/es901825t.
Winkel, L./Berg, M./Stengel, C./Rosenberg, T. (2008). Hydrogeological survey assessing arsenic and other groundwater contaminants in the lowlands of Sumatra, Indonesia. Applied Geochemistry 23 (11), 3019-3028. https://doi.org/10.1016/j.apgeochem.2008.06.021.

World Health Organization (2003). Arsenic in drinkingwater. background document for development of WHO guidelines for drinking-water quality. Geneva, WHO.

Wyllie, J. (1937). An investigation of the source of arsenic in a well water. Canadian Public Health Journal 3 (28), 128-135. Available online at https://www.jstor.org/stable/41977559.

Xie, X./Johnson, T. M./Wang, Y./Lundstrom, C. C./Ellis, A./Wang, X./Duan, M. (2013). Mobilization of arsenic in aquifers from the Datong Basin, China: evidence from geochemical and iron isotopic data. Chemosphere 90 (6), 1878-1884. https://doi.org/10.1016/j.chemosphere.2012.10.012.

Xie, X./Wang, Y./Duan, M./Liu, H. (2009). Sediment geochemistry and arsenic mobilization in shallow aquifers of the Datong basin, northern China. Environmental Geochemistry and Health 31 (4), 493-502. https://doi. org/10.1007/s10653-008-9204-7.

Yadav, I C./Singh, S./Devi, N. L./Mohan, D./Pahari, M./Tater, P. S./Shakya, B. M. (2012). Spatial distribution of arsenic in groundwater of southern Nepal. Reviews of Environmental Contamination and Toxicology 218, 125-140. https://doi.org/10.1007/978-1-4614-3137-4_3.

Yuan, C./Lu, X./Oro, N./Wang, Z./Xia, Y./Wade, T. J./Mumford, J./Le, X. C. (2008). Arsenic speciation analysis in human saliva. Clinical Chemistry 54 (1), 163-171. https://doi.org/10.1373/clinchem.2007.092189.

Yuan, T./Zhang, H./Chen, B./Tao, S. (2018). Association between lung cancer risk and inorganic arsenic concentration in drinking water: a dose-response meta-analysis. Toxicology Research 7 (6), 1257-1266. https://doi.org/10.1039/c8tx00177d.

Yunus, F. M./Khan, S./Chowdhury, P./Milton, A. H./Hussain, S./Rahman, M. (2016). A review of groundwater arsenic contamination in Bangladesh: the Millennium Development Goal era and beyond. International Journal of Environmental Research and Public Health 13 (2), 215. https://doi.org/10.3390/ijerph13020215.

Zablotska, L. B./Chen, Y./Graziano, J. H./Parvez, F./van Geen, A./Howe, G. R./Ahsan, H. (2008). Protective effects of B vitamins and antioxidants on the risk of arsenic-related skin lesions in Bangladesh. Environmental Health Perspectives 116 (8), 1056-1062. https://doi.org/10.1289/ehp.10707.

Zeng, Q./Zhang, A: (2020). Assessing potential mechanisms of arsenic-induced skin lesions and cancers: human and in vitro evidence. Environmental Pollution 260. https://doi.org/10.1016/j.envpol.2020.113919.

Zhang, Q./Rodríguez-Lado, L./Johnson, C. A./Xue, H./Shi, J./Zheng, Q./Sun, G. (2012). Predicting the risk of arsenic contaminated groundwater in Shanxi Province, Northern China. Environmental Pollution 165, 118-123. https://doi.org/10.1016/j.envpol.2012.02.020. 